\title{
Dynamic Viral Glycoprotein Machines: Approaches for Probing Transient States That Drive Membrane Fusion
}

\author{
Natalie K. Garcia and Kelly K. Lee * \\ Received: 20 October 2015; Accepted: 31 December 2015; Published: 11 January 2016 \\ Academic Editor: Andrew Ward \\ Department of Medicinal Chemistry, University of Washington, Seattle, WA 98195, USA; nkgarcia@uw.edu \\ * Correspondence: kklee@uw.edu; Tel.: +1-206-616-3972; Fax: +1-206-685-3252
}

\begin{abstract}
The fusion glycoproteins that decorate the surface of enveloped viruses undergo dramatic conformational changes in the course of engaging with target cells through receptor interactions and during cell entry. These refolding events ultimately drive the fusion of viral and cellular membranes leading to delivery of the genetic cargo. While well-established methods for structure determination such as X-ray crystallography have provided detailed structures of fusion proteins in the pre- and post-fusion fusion states, to understand mechanistically how these fusion glycoproteins perform their structural calisthenics and drive membrane fusion requires new analytical approaches that enable dynamic intermediate states to be probed. Methods including structural mass spectrometry, small-angle X-ray scattering, and electron microscopy have begun to provide new insight into pathways of conformational change and fusion protein function. In combination, the approaches provide a significantly richer portrait of viral fusion glycoprotein structural variation and fusion activation as well as inhibition by neutralizing agents. Here recent studies that highlight the utility of these complementary approaches will be reviewed with a focus on the well-characterized influenza virus hemagglutinin fusion glycoprotein system.
\end{abstract}

Keywords: viral membrane fusion glycoprotein; structural mass spectrometry; electron microscopy; small-angle X-ray scattering; hydrogen-deuterium

\section{Introduction}

Enveloped viruses bear a host-derived lipid membrane that encapsulates and protects the viral genetic material. To infect new cells and deliver the viral genome into the host cell cytoplasm, the virus must open a conduit across the membrane barrier by merging its lipid envelope with a host cell membrane. Fusion glycoproteins (abbreviated gp or GP depending on virus type) anchored to the virus membrane and displayed on the virus surface mediate this essential process. To understand the function of these cell entry machines requires detailed structural characterization and elucidation of the conformational transitions and intermediate states that are populated during the fusion process. In addition, many of the viruses, particularly those with RNA genomes, exhibit significant variation due to mutational drift and selection. The differences in amino acid sequence impact glycoprotein structure, antigenicity and fusion protein function during cell entry. Yet our understanding of the link between sequence, structural variation, phenotype and function are still in their infancy.

Viral fusion glycoproteins are often challenging targets for high-resolution structural characterization due to their decoration with flexible and heterogeneous glycans, intrinsic structural dynamics, and instability of the native, metastable pre-fusion states. In recent years, a diverse array of biophysical methods have been applied that: (i) provide complementary insights into the nature of conformational changes during fusion activation and neutralizing antibody engagement [1-13]; 
(ii) reveal the flickering, transient conformational sampling exhibited by glycoproteins on the surface of virions [12,14]; and (iii) illuminate variations in structural dynamics that impact the antigenicity and receptor reactivity of viral glycoprotein components [15-17]. In this review, we will describe a set of biophysical methods that have recently provided new perspectives on viral fusion protein structure and function, and present the influenza hemagglutinin (HA) system as a prime example of how the various methods can combine to give a more complete understanding of this dynamic fusion machine. We also highlight developing areas that may benefit from application of these new approaches.

Influenza HA is the best characterized type-I fusion protein, with high-resolution structures of pre- and post-fusion conformations [18,19], a multitude of neutralizing antibody fragment antigen binding (Fab) domains that have been characterized in complex with the glycoprotein antigen [20-29], a detailed 3-dimensional understanding of virus ultrastructure [30-34], and decades of biophysical characterization [1,11,13,35-47]. Despite this wealth of information, until recently we have lacked structural information describing the sequence of changes exhibited by hemagglutinin during fusion, and even basic information for the nature of target and virus membrane deformations that hemagglutinin induces in order to drive membrane fusion is unclear.

Like other type-I fusion proteins, HA is a homo-trimer of hetero-dimeric protomers [18]. One subunit in the protomer, HA1, is responsible for receptor binding, and a second, HA2, is the primary fusion machinery. In analogous fusion systems such as the human immunodeficiency virus (HIV) envelope glycoprotein (Env), receptor binding induces major conformation changes in the receptor binding subunit [48-53], which are transduced to the fusion subunit leading to its priming and activation [2]. HA attachment to extracellular sialic acids on glycoproteins and glycolipids on the cell surface initiates the influenza virus infection cycle (Figure 1) [54-57]; however, no evidence has been found to indicate that sialic acid receptor binding induces a structural change or activation of the HA fusion machinery. The low, $\sim \mathrm{mM}$ affinity of sialic acid for the receptor binding site suggests that high avidity binding of three sialic acid binding sites per trimer, multiplied over several trimeric spikes on a virus-host membrane contact surface is needed to adsorb the virus to the cell surface [58-60]. 300-500 of the trimeric HA spikes are present on typical influenza virus particles, in $\sim 5$-fold copy number excess over the other surface protein, neuraminidase, which has an essential sialidase activity needed to release newly budded virions from the cell surface $[30,61,62]$. Multivalent sialic acid receptor engagement through HA appears to trigger endocytosis of the virus, rather than entry occurring at pre-existing endocytosis hotspots [46,47].

Influenza $\mathrm{HA}$ activation is triggered by exposure to the acidic $\mathrm{pH}$ within maturing endosomes $(\mathrm{pH}$ 6.0-5.0), resulting in the complete structural rearrangement of the fusion protein $[18,19,46,57,63,64]$. Early differential scanning calorimetry experiments indicated that HA is kinetically trapped in a metastable conformation, which upon conversion to the post-fusion state, releases conformational energy to help drive membrane apposition and fusion [35-39,57,64-66]. Carr and Kim first described the mechanism as a "spring-loaded" change [35] in which a loop in pre-fusion HA irreversibly becomes helical at low $\mathrm{pH}$ in order to extend the central helical bundle and relocate the fusion peptide at the N-terminus of HA2 from close to the base of the trimer $\sim 100 \AA$ towards the viral membrane. The structure of a post-fusion HA soluble fragment (TBHA2) where BHA was treated with low $\mathrm{pH}$ and proteolyzed to remove HA1 and the fusion peptide also revealed that HA2 refolding involved a helical break that permits the C-terminal portion of the subunit to repack along the newly extended core [19]. In a related study of HIV gp41 by Weisenhorn et al. [67], it was proposed that this refolding of the C-terminal segment of the fusion subunit along the central helical bundle drives membrane fusion. Indeed in the post-fusion state, the $\mathrm{N}$-terminal fusion peptide and C-terminal membrane anchor region are colocalized, consistent with their role in juxtaposing the two membranes to induce their fusion. When HA2 was expressed recombinantly in E. coli the fold observed in the post-fusion TBHA2 structure was found to be the low energy conformation for the HA2 polypeptide sequence [68]. Subsequent analysis suggests that prior to the adoption of the ultimate post-fusion state, 
reversible stages of conformational change exist and these appear to play important roles in initiating engagement of the target membranes [32,38,40,41,64,69-71].

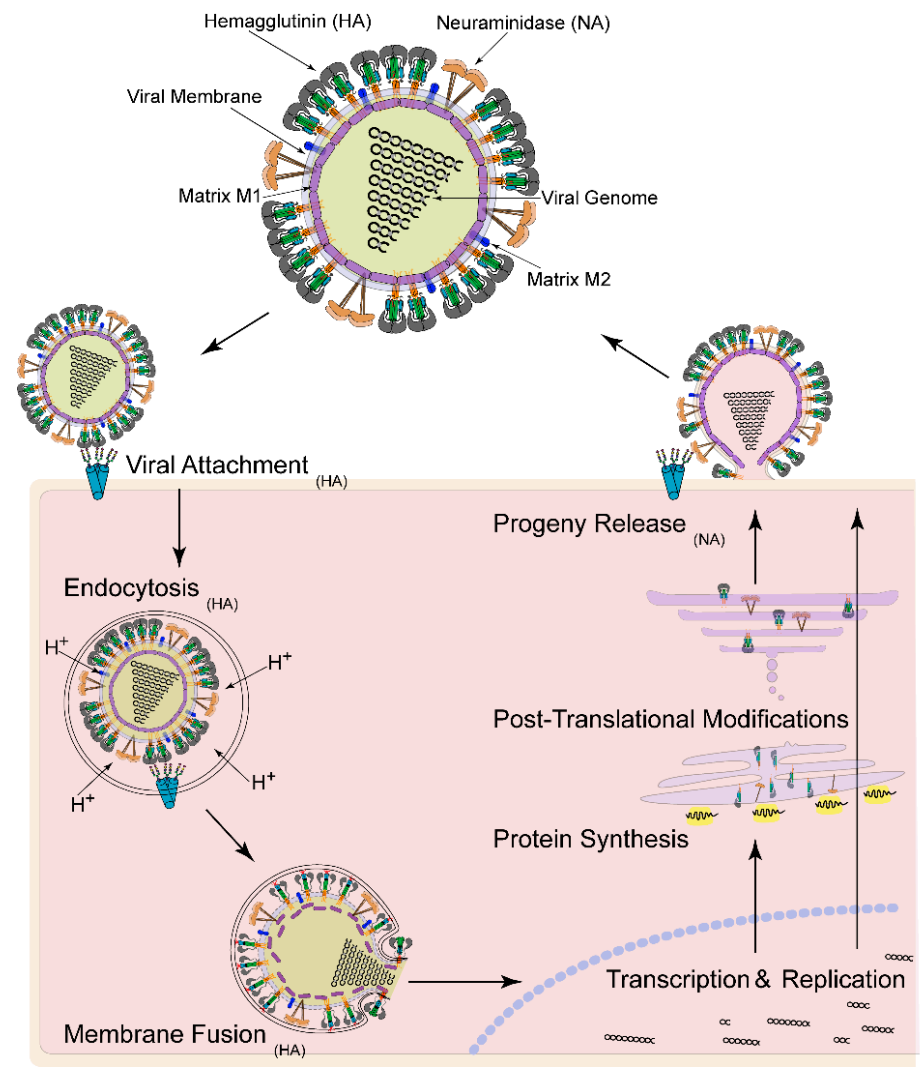

Figure 1. Influenza virus structure and infectious cycle. Viral attachment is mediated by Hemagglutinin (HA), which bind through multi-valent, high avidity interactions to host cell surface glycans, triggering endocytosis of the virus particle. Following acidification of the endosomal lumen, M1 dissociates from the inner surface of the viral membrane, and HA undergoes large structural changes to drive membrane fusion ultimately releasing the nucleoprotein-coated genome segments into the cytosol, which is transported to the nucleus for genome transcription and replication. Viral proteins are synthesized and post-translationally modified via the endoplasmic reticulum and trans-golgi network. Progeny viruses are assembled at the cell surface, where Neuraminidase (NA) cleaves neighboring sialic acid for release of newly formed virus into the extracellular milieu.

In addition to influenza HA, high-resolution structures have been determined for other type-I fusion glycoproteins in their pre-fusion states including paramyxovirus F proteins [72-74], major portions of the Ebola glycoprotein (GP) [75,76], and the HIV Env glycoprotein in an engineered, mutation stabilized form, allowing identification of receptor binding sites and organization of the receptor binding and fusion subunit $[7,8,14,77]$. This information has proved exceptionally informative for understanding the viral spike structures and disposition of epitopes for neutralizing antibodies, which most frequently target the pre-fusion conformation of the glycoprotein antigens on the virus surface.

Structures of fragments of the proteins in the low-energy, post-fusion conformations have also been reported. The post-fusion "hairpin" structures of type-I fusion proteins such as HIV Env gp41 and Ebola GP2 revealed commonality of presumed fusion mechanisms, highlighting the end-stage colocalization of $\mathrm{N}$ and C-terminal, membrane-active subdomains in the post-fusion conformation $[19,67,68,78-81]$. Metastability of the pre-fusion conformation and the low energy, ground state character of the post-fusion conformation are believed to be common traits for type-I fusion proteins. What remains for 
all of these systems is to understand the pathways of conformational change that link the beginning and end states, and that in fact actively manipulate membranes and drive the fusion reactions to completion. Such a challenging task is becoming tractable through the development of biophysical methods that enable proteins in dynamic, transient states to be analyzed under a broad range of solution conditions.

\section{Solution-Based Biophysical Approaches}

Solution-phase protein labeling experiments in conjunction with mass spectrometry (MS) is a growing field in structural biology (Figure 2A,B), providing sequence-specific information about native protein conformational dynamics and structural organization. These approaches, including hydrogen/deuterium-exchange mass spectrometry (HDX-MS) and oxidative radical footprinting followed by MS analysis, can be applied to a broad range of proteins, glycoproteins, membrane-bound proteins and even proteins in the context of whole virus particles [1,82-87]. Protein size is less of a limiting factor than for example with nuclear magnetic resonance (NMR) spectroscopy, which also can be used to probe structural dynamics of smaller macromolecules but is less suitable for analysis of objects in the size range of viral glycoproteins. With the advent of more advanced mass spectrometers such as those employing ion mobility separation for enhanced identification of peptide fragments, it is becoming possible to analyze even more complex targets [88]. The mass spectrometry-based methods are particularly powerful when applied to compare differences resulting from changes in solution conditions, or between two related variants such as mutant and wild-type proteins, or proteins in ligand-bound and free states, where for example one can map antibody epitopes within an antibody-antigen complexes [89-92].

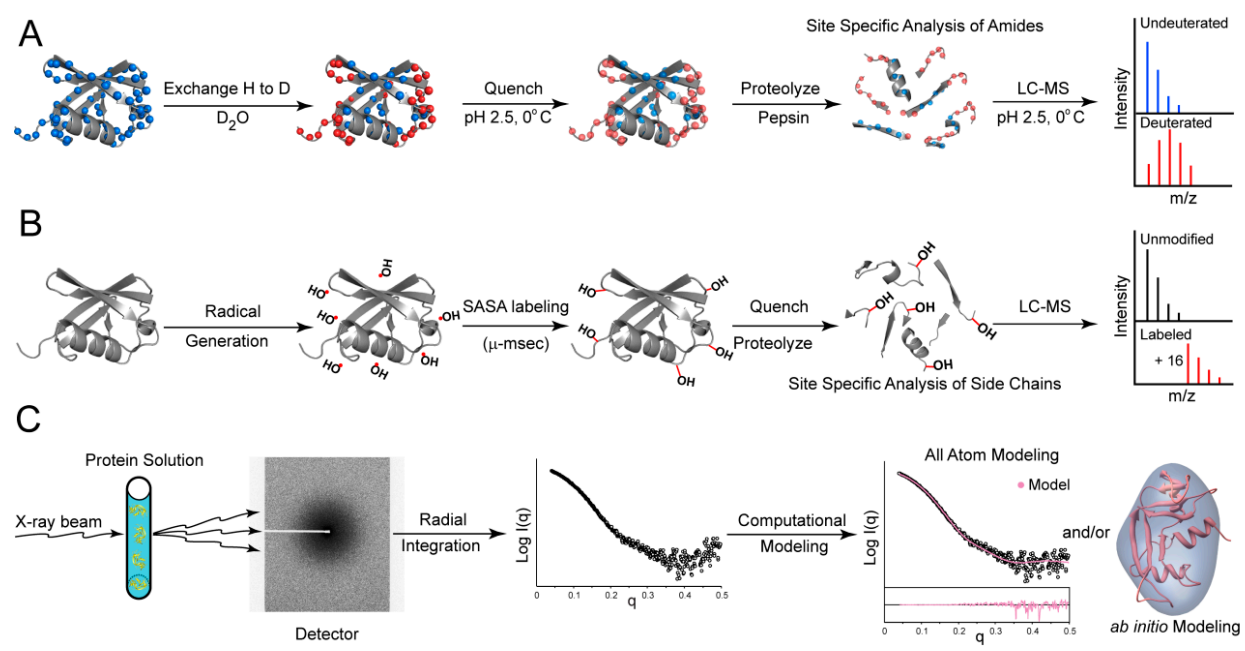

Figure 2. Solution Based Approaches for Protein Characterization (A) Hydrogen-Deuterium Exchange Mass Spectrometry (HDX-MS). Exchange of backbone amide protons for deuterons is initiation by incubating a protein in deuterated buffer for various amounts of time, reaction is quenched at $\mathrm{pH} 2.5$ and on ice, samples are denatured and digested, and mass shifts are analyzed by mass spectrometry; (B) Oxidative Labeling MS. Biological macromolecules in solution are exposed to hydroxyl radicals for various periods of time, which covalently modify solvent accessible surface area (SASA) via amino acid side chains. Radicals can be rapidly generated by radiolysis of water or photolysis of hydrogen peroxide, or slowly generated using Fenton's reagents. The reaction is quenched using radical scavengers and the samples are proteolyzed and analyzed by mass spectrometry; (C) Small Angle X-ray Scattering (SAXS). Biological macromolecules in solution are irradiated with a monochromatic X-ray beam, which generate a characteristic scattering pattern. Computational methods such as all-atom modeling can be used to compare high-resolution structures to the solution-phase data, or ab initio shape reconstruction can be used to generate low-resolution morphological information. 


\section{Hydrogen-Deuterium Exchange Mass Spectrometry (HDX-MS)}

HDX-MS (Figure 2A) probes local structural dynamics in native proteins and glycoproteins yielding a "fingerprint" of structural dynamics with sensitivity necessary to identify isolate-specific differences in structure and the ability to identify ligand-induced structural changes $[15-17,93]$. By itself this approach does not provide 3-dimensional structural information; rather one obtains a measurement of structural dynamics or flexibility of segments of the protein as they exist under native conditions in the folded protein. In combination with other available structural information, HDX-MS can be a powerful method for mapping conformational changes and characterizing structures that may be too dynamic and flexible to characterize by crystallography or electron microscopy (EM).

HDX-MS measures the rate of deuterium incorporation at the backbone amides, which is dependent upon fluctuations in local structural order. The apparent deuterium exchange rates of each amide in the protein polypeptide backbone is predominately influenced by hydrogen bonding, such as in secondary structure formation, while solvent occlusion plays less dominate role $[89,93]$. The protein is incubated in $\mathrm{D}_{2} \mathrm{O}$-based buffer under native conditions for a range of times, after which, the solution is acidified to $\mathrm{pH} 2.5$ to slow deuterium exchange at the amides. Structural analysis of the protein requires proteolytic digestion of the partially deuterated protein under quench conditions using acid-active proteases such as pepsin. The peptic fragments are resolved chromatographically and analyzed by mass spectrometry. The extent of deuterium up-take for each peptide is interpreted by the mass shift as a function of deuteration time.

The reliance upon the acid-active protease, pepsin, imposes one major limitation in HDX-MS analysis in the form of non-uniform sequence resolution. Pepsin reproducibly cleaves the polypeptide into a range of segments of varying length [94]. As a result, one obtains peptides that range from a few to tens of residues in length. Addition of methods such as electron transfer dissociation (ETD) for the further fragmentation of peptides in the mass spectrometer can in some cases increase resolution down to individual residues [95]. Thus far, ETD has only been applied for a few studies, but with increasing availability of appropriate instrumentation and software development it is becoming of greater utility for HDX-MS [96,97]. The use of acid-active protease that cleave with different specificities to pepsin may offer a way of providing complementary peptide coverage and generating an overlapping mosaic of exchange profiles based on the two separate or combined proteolytic activities [98,99].

In the analysis of glycoproteins, resistance to proteolysis and poor signal for glycopeptides complicates analysis $[100,101]$. Hyperglycosylated regions within a protein typically generate large peptic fragments that may contain multiple glycans per peptide. In some cases the highly glycosylated peptides bind poorly to the reverse-phase columns implemented during liquid chromatography. Microheterogeneity of glycoforms at each $\mathrm{N}$ or $\mathrm{O}$-linked glycosylation site results in the signal for a glycosylated peptide to be distributed among several glycoform variants, and in the case of poorly ionizable peptides, can significantly hamper detection.

While the vast majority of structural information for influenza HA as well as other viral glycoproteins has come from high-resolution structural analysis of soluble constructs produced either recombinantly or by proteolytically cleaving the proteins from intact virus, it is important to confirm that the soluble form of the protein retains the native structure found on the intact virion. For influenza HA this has been now demonstrated at low-resolution using cryo-electron tomography [30,31,34] as well as in greater, sequence-specific detail by HDX-MS in which soluble, bromelain-released HA (BHA) from A/Aichi/68/H3N2 was shown to exhibit a nearly superimposable HDX profile as HA on intact virus particles at neutral $\mathrm{pH}$ [1].

The ability to vary solution conditions and analyze structure by HDX-MS enabled mechanisms of influenza HA activation to be investigated by comparing the structure of HA under pre-fusion and post-fusion conditions and under $\mathrm{pH}$ conditions approaching the threshold for activation [1]. This has helped to provide a more complete understanding of the post-fusion organization of the full HA ectodomain. High-resolution structural characterization of post-fusion HA is limited to the HA2 ectodomain and does not provide information about the post-fusion HA1 conformation. HA1 
monomers proteolyzed from acid-treated viral HA, complexed with an antibody Fab domain and crystallized at pH 6.0 indicated that the overall morphology of HA1 remains similar to that seen in the pre-fusion trimer [23]. HDX-MS analysis of HA1 in the context of the BHA trimer ectodomain, however, exhibited much greater levels of structural dynamics than observed in the pre-fusion state suggesting the HA1 receptor binding subunit loses much of its integrity following conversion to the post-fusion state.

HDX-MS analysis of BHA also demonstrated that at $\mathrm{pH}$ values approaching fusion activation for this isolate ( $\mathrm{pH}$ 5.5), major increases in local conformational flexibility were observed at the fusion peptide and HA1 hinge proximal to the HA1-HA2 interface (Figure 3) [1]. The use of an internal standard peptide containing a single exchangeable site along with incubation time adjustments was necessary to account for the $\mathrm{pH}$-dependence of the intrinsic exchange rates during labeling [1,102]. Previous structures obtained from HA mutants crystallized at conditions approaching fusion, suggested that rotations within the B-loop and adjacent HA1 residues may, in part, initiate HA activation $[69,103]$. Some of the local structural changes detected by HDX-MS echoed these results, however, the solution-phase analysis of the $\mathrm{H3}$ Aichi / $68 \mathrm{BHA}$ demonstrated that the fusion peptide and associated structural regions become highly dynamic as the $\mathrm{pH}$ of fusion is approached, which was not observed by crystallography $[69,103]$. Furthermore, the HDX-MS data revealed moderate stabilization of the HA1-HA1 trimeric interface under fusion-activation conditions, in apparent contradiction of HA1 domain dissociation or "uncaging" of the HA2 fusion subunit, which is often implicitly assumed to initiate the fusion process (Figure 3). Instead, the recent data suggests that HA activation is initiated by fusion peptide release and reorganization, which does not require a large-scale opening of the trimeric spike. This pathway would appear to allow fusion peptides to bind target membranes prior to unleashing the full HA2 "spring-loaded" transition.

Recent cryo-electron tomograms of influenza virus acidified to $\mathrm{pH} 4.9$ and frozen after $5 \mathrm{~min}$ at room temperature provided a low-resolution glimpse of an HA intermediate that is consistent with HDX-MS data, displaying a narrowing of the HA2 stalk region while density for the globular head remained intact [32]. As with all low-resolution methods, validation by orthogonal methods and testing for consistency against available biochemical data is desirable. Investigations characterizing HA activation intermediates by White and Wilson in 1987 used antibodies that recognize specific conformational epitopes on HA [104]. The experiments showed that the fusion peptide release from the fusion peptide pocket precedes exposure of epitopes at the HA1 globular head domain interfaces that are occluded in the pre-fusion structure. In a follow-up study by Kemble et al. [105], it was reported that fusion peptide exposure was concurrent with minor changes in the membrane distal apex of the trimer that occurred prior to HA1 dissociation (Figure 3). This antibody mapping data is thus consistent with the model suggested by HDX-MS for changes in HA during acid-induced fusion activation at least for the A/Aichi/68 H3 HA that has been most intensively examined. It remains to be determined whether HA from other subtypes exhibits similar changes upon activation. We note that crystallography was performed with two "group 1" HA trimers, from H2 and H5 isolates, while the HDX-MS analysis examined a "group 2" HA from an H3 virus. Given the different propensities to inactivation that have been reported for different viral isolates $[13,41,42,71]$, it may be the case that the HA stability, fusion activation and transience of intermediate conformations vary between isolates. Further studies assessing the isolate-specific dynamics during fusion activation are needed to truly answer these remaining questions.

Indeed in the case of highly variable viruses such as HIV and influenza, it is desirable to understand the structural basis that governs the functional and antigenic properties for each isolates, in hopes to find a common therapeutic target $[13,42,106,107]$. The ability to analyze protein structure under native solution conditions for glycoproteins by HDX-MS has made it possible to perform comparisons of glycoprotein constructs from highly divergent viral isolates [2,15]. The structural differences that are evident when glycoproteins such as HA and HIV Env are studied under native solution conditions are often suppressed by removal of variable elements, partial deglycosylation, 
complex formation with stabilizing ligands such as Fabs and the constraints of crystallization itself $[15,53,108]$.

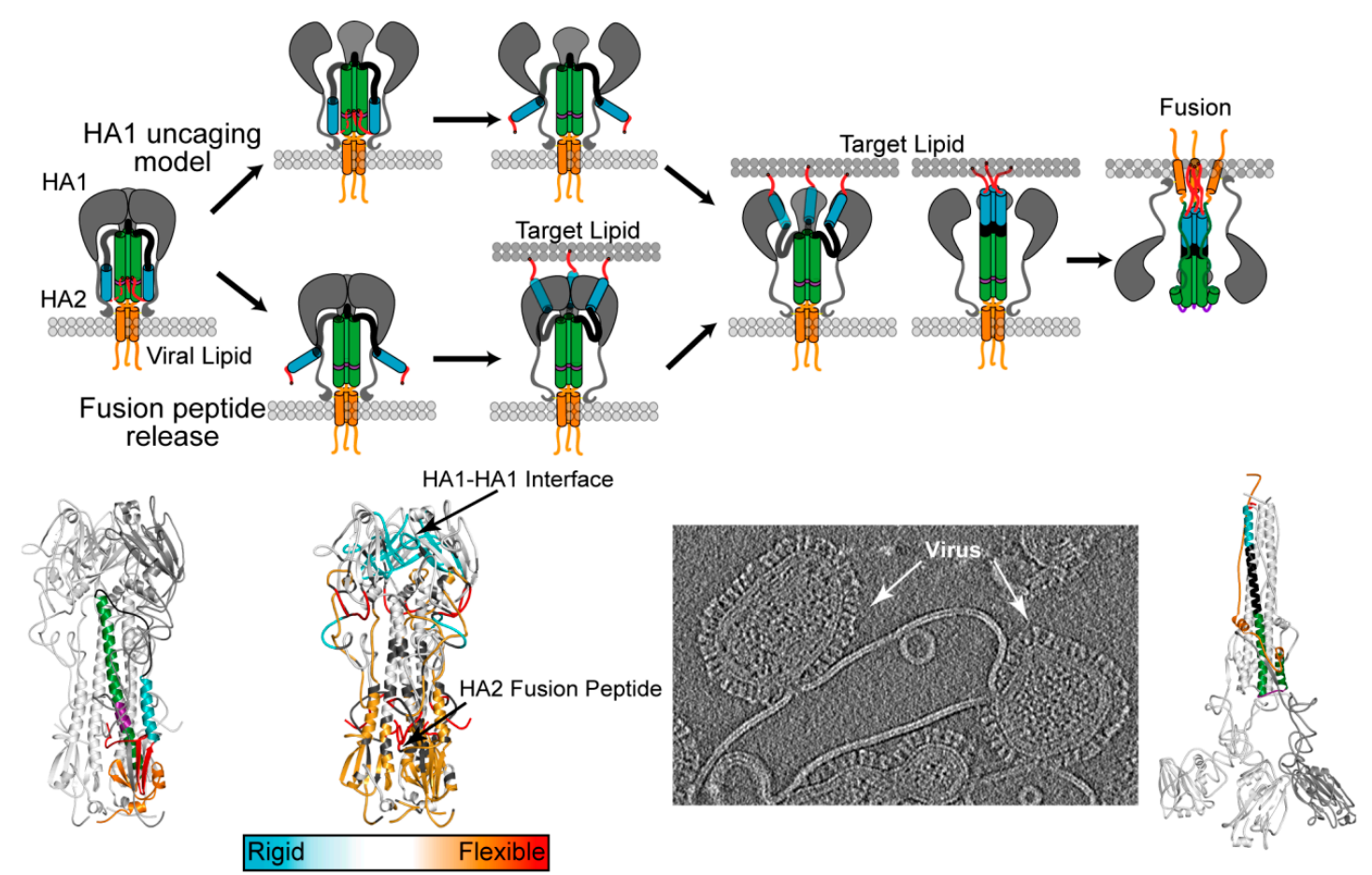

Pre-Fusion HA

HA dynamics at $\mathrm{pH} 5.5$

HA-mediated membrane remodeling Post-Fusion HA

Figure 3. Influenza Hemagglutinin pH-Activation Models. Pre-fusion HA is composed of the two subunits, HA1 (grey) and HA2 fusion domain with the fusion peptide and proximal regions (red), the short helix (blue), the B-loop (black), the long helix (green and purple), and the C-terminal regions (orange), colored identically on $3 \mathrm{HMG}$ crystal structure below. The $\mathrm{pH}$-dependent membrane fusion is hypothesized to commence either by the uncaging of HA1 (top pathway) from the HA2 fusion machinery, or by the release of the fusion peptide from the core of the trimer (bottom pathway). Once the fusion peptide is released, it binds the target membrane and the subsequent refolding of the B-loop and long helix (purple), drives the fusion of the viral membrane with the target membrane. Membrane fusion ends in the post-fusion conformation depicted in the bottom panel where HA1 lobes are modeled onto the 1QU1 crystal structure. Recent solution-based techniques such as HDX-MS and cryo-electron tomography have provided evidence for the fusion peptide release model for H3 HA isolate fusion activation. The HDX dynamic changes are illustrated as regions more flexible at low $\mathrm{pH}$ (red) colors and more ordered regions at low $\mathrm{pH}$ (blue). In the cryo-electron tomogram, acid-activated influenza virus is shown at early stages of membrane fusion with a synthetic liposome.

HDX-MS has also provided significant new information about the initial stages of HIV Env activation upon CD4 receptor binding [2,15,52,53], which had previously been inferred at low-resolution from EM studies [4-6,109] or crystal structures of truncated subunit constructs [49,50]. HDX-MS was used to compare native-like Env trimers (SOSIP.664 constructs [10]) in an unliganded and in CD4-bound forms (using a soluble, 2-domain form of CD4) [2]. Illustrating the specificity of structural perturbations that can be detected by this method, two distinct allosteric networks were found to be engaged by CD4 binding: one leading to opening of the trimer apex and coreceptor binding site exposure, and a second involving priming of the gp41 fusion subunit. HDX-MS has also distinguished the distinct binding modes for two CD4 binding site-targeted broadly neutralizing antibodies (bNAbs), VRC01 and b12. These comparisons revealed the trimer stabilizing effect in the case of VRC01 and the apparent destabilizing effects of b12 [3]. The HDX-MS observations of the soluble trimeric Env constructs in complex with highly potent bNAb and CD4 are consistent with 
recent studies using single-molecule Förster resonance energy transfer (sm-FRET) to monitor the dynamic conformational sampling of HIV Env on the surface of virus particles in complex with CD4 and a panel of bNAbs including VRC01 [12].

Analysis of conformational dynamics and structural order by HDX-MS of viral glycoproteins from other enveloped viruses has been reported recently as well. HDX-MS was used to examine the impact of proteolytic processing of the Ebola virus GP and dynamic changes within antigenically distinct GPs [16,17]. Identification of flexible residues within the hypervariable regions of a deglycosylated ectodomain construct of the E2 glycoprotein from hepatitis C virus (HCV) was made possible with the aid of HDX-MS [110]. This highlights another useful application of HDX-MS in identification of highly flexible, dynamic regions that can be truncated to facilitate crystallization. The synergy between HDX-MS and electron microscopy was also useful for identifying the architecture of the human cytomegalovirus (HCMV) glycoprotein entry complexes and for identifying the discontinuous conformational epitope of a neutralizing antibody [111]. Investigations of temperature-dependent changes in global and local structure as probed by cryo-EM and HDX-MS in the context of an intact dengue virus particles have also been reported [84]. These varied studies highlight the versatility of HDX-MS for structural and functional analysis of diverse viral glycoproteins under a broad spectrum of solution conditions.

Lastly, HDX-MS has utility in validating whether proteins are natively folded. This is an important consideration in the development of subunit-based immunogens for viral vaccines. The ability for a protein-subunit vaccine construct to elicit an antibody-immune response is likely contingent upon having properly folded immunogens that present authentic epitopes to the immune system. HDX-MS can provide rigorous assessment of whether proteins are natively folded and in the expected conformation and organization $[112,113]$. Such approaches have been gaining utility in the analysis of protein biologics with respects to storage and formulation conditions, which may become a gold-standard required by the Food and Drug Administration [101,114-116].

\section{Oxidative Labeling With Mass Spectrometry}

Complementary to HDX-MS, which is highly influenced by secondary structure, oxidative labeling analyzed by mass spectrometry (Figure 2B) utilizes hydroxyl radicals generated rapidly by either synchrotron $\mathrm{X}$-ray radiolysis of water or ultraviolet laser photolysis of hydrogen peroxide to covalently modify solvent accessible amino acid side chains in proteins and in complexes [82,90,117-119]. By probing side-chain reactivity to radicals in bulk solvent, oxidative radical labeling allows solvent-accessible protein surfaces to be mapped [85,87,118-121]. In addition, the versatility of the both methods to be performed under a broad range of solution conditions enables the analysis of large dynamic protein systems that require atypical environments (e.g., detergents, low $\mathrm{pH}$ ) $[82,86]$.

The oxidative labeling approach has revealed conformational changes in viral antigens such as in a domain from the HIV gp120 receptor binding subunit [122]. It has been used to map interaction interfaces with neutralizing antibodies, as well as to probe the structural changes in trimeric HIV Env in response to $\mathrm{CD} 4$ binding $[2,123]$. More recently, a study combining temperature-activation and oxidative labeling of the fusion protein from parainfluenza virus 5, identified differences in solvent accessibility and structural reorganization between pre-fusion and post-fusion conformations [124].

A limitation of the oxidative labeling approach is that different amino acid side chains have different intrinsic reactivities with radicals. The residues one can monitor may be unevenly and infrequently distributed throughout the protein sequence and structure, giving rise to relatively sparse sampling of solvent accessibility throughout the folded protein. The ability for other solution components to react and scavenge the radicals should also be considered during experimentation $[90,125,126]$. Proteins are also susceptible to oxidative damage, and rapid generation and labeling times are necessary to prevent denaturation during labeling, which may convolute interpretation $[87,121]$. 


\section{Small Angle X-Ray Scattering (SAXS)}

SAXS (Figure 2C) is useful technique that involves the measurement of elastic X-ray scattering from macromolecules in solution. The SAXS pattern one obtains is directly related to the 3-dimensional organization of atoms in the scattering object, hence one can extract structural information from the measured SAXS data $[127,128]$. In the most elementary application, SAXS can be used to determine accurate protein and glycoprotein molecular weights [15,52,113,129-133]. Radii of gyration and maximum point-to-point dimensions of the scattering object can also be readily obtained. With $a b$ initio shape reconstruction programs, the scattering pattern can yield low-resolution morphologies of proteins and protein complexes in solution (Figure 2C) [128,134-136].

A particularly powerful approach has come into use more recently in which one builds upon sometimes fragmentary high-resolution structural information by modeling in missing features and iteratively changing and selecting models that produce optimal agreement with experimentally measured SAXS data [137-141]. It is important to note that the solution scattering profile results from the entirety of scattering correlations of atoms in the object of interest, hence it is essential to model in not just missing protein loops but to include glycans and other post-translational modifications as well $[132,133]$. With the experimental SAXS pattern as a constraint, in simpler cases, it is possible to identify ensembles of models with glycan orientations that show a better agreement with the measured data, allowing the spatial occupancy of the glycans to be estimated [132]. In ab initio modeling, due to averaging effects and limitations on resolution, glycans tend to not be well resolved [52,132].

When applied to examine structural integrity and changes in conformation during acid-induced activation of bromelain-released HA, SAXS demonstrated that at $\mathrm{pH} 5.25$, the spike ectodomain largely retained its pre-fusion-like organization, i.e., without HA1 domain dissociation and HA2 springing to the helical bundle post-fusion state, though subtle structural changes that were consistent with the more detailed HDX-MS results were observed [1]. SAXS has been applied to analyze glycosylated HIV Env gp120 subunits, which at $\sim 110 \mathrm{kDa}$ including $50 \%$ glycans by mass are generally too small for detailed EM analysis and too large for NMR [15,52,142]. SAXS revealed the orientation of the large V1/V2 hypervariable loops relative to the gp120 core and showed that V1/V2 shift in position following CD4 binding [52]. SAXS also demonstrated that while they may exhibit significant differences in local structural order, divergent gp120s retain similar global organizations [15]. SAXS thus fills an important niche in providing structural characterization, albeit at low-resolution, of even relatively small glycoprotein constructs, and is considerably less limited on the other end of the spectrum for analysis of large proteins and complexes including even whole icosahedral capsids [143-149].

SAXS has also been used to map the position of a neutralizing antibody Fabs bound to a trimeric form of HIV Env, showing good agreement with a low-resolution negative stain EM reconstruction [150]. The implementation of SAXS was also useful for identifying different binding modes of a cross-reactive neutralizing human antibody to the heavily glycosylated filovirus GP glycoprotein from Marburg and Ebola, which were refractory to crystallography [149]. In examination of receptor binding interactions with HCV E2 glycosylated ectodomain and core constructs, SAXS proved useful in interpretation of possible binding models [110].

\section{Electron Microscopy (EM)}

EM is experiencing major advances in both attainable resolution and an increasingly powerful ability to grapple with heterogeneous, conformationally variable samples over a range of sizes from $\sim 200 \mathrm{kDa}$ to megadalton structures [151,152]. Because the specimens do not require crystallization, they can be examined under a range of solution conditions and complexed with a range of ligands. By single-particle analysis, starting with relatively pure samples, a 3-dimensional reconstruction of viral glycoproteins alone or in complex with antibody Fab fragments can be obtained [153]. By electron tomography (ET), complex, asymmetric and heterogeneous specimens can be imaged to characterize virus ultrastructure [154-156]; this is useful for example in imaging glycoprotein distribution, orientation and interaction with other ligands or receptors. 
Much like an X-ray CAT (computer assisted tomography) scans, ET enables 3D reconstructions to be built from 2D projections gathered at different specimen tilt angles. Cryo-ET has also been used to probe the structure of diverse enveloped viruses [30,34,157-167]. The method is also a powerful means for imaging biological processes such as virus undergoing membrane fusion with vesicles [31,168,169], virus entry into intact cells grown on EM grids [170], virus budding from cells [171-173], and virus maturation [174-177], to name just a few fundamental aspects of enveloped virus biology. With cryo-ET, resolution is typically limited to $\sim 10-20 \AA$, and due to the incomplete sampling of angular orientations (mechanical constraints limit tilt angles to $\sim \pm 70^{\circ}$ ), information for the top and bottom of objects tend to be poorly represented in the final reconstructions. However, in many cases, density in reconstructed electron tomograms corresponding to surface glycoproteins can be clearly resolved and is often found to be in excellent agreement with available high-resolution crystal structures $[4,30,31,162,178]$.

In imaging influenza HA under fusogenic conditions, cryo-ET has proven to be a uniquely well-suited approach that enables virus-liposome complexes to be imaged with resolution of membrane leaflets, coordinated HA spikes and other viral components such as the M1 matrix layer that plays a critical role in virion assembly as well as during fusion [31-33]. Intriguingly, at many of the sites of nascent pore formation, when the target membrane is being drawn as a dimple towards the virus envelope by a localized cluster of HA, distinct " $\mathrm{V}$ " or " $\mathrm{Y}$ " shaped densities are observed coordinating the dimple [31]. This suggests an intermediate state of HA undergoing the refolding process with the central HA2 helical bundle being extended but the C-terminal "leash" parts of the subunit that are anchored to the viral membrane only partially docked into the grooves of the bundle [31,179]. Observation of such intermediate structures is likely only feasible when full-length HA natively presented on a membrane is grappling with the target membrane.

Sub-tomogram averaging can be applied to enhance definition of glycoprotein density. This method involves "boxing" out sub-volumes from larger 3D reconstructed fields of view and averaging the individual boxed structures to increase signal-to-noise of common density features while suppressing density for conformationally variable elements [180]. Cryo-ET with sub-tomogram averaging has addressed important controversies in HIV Env structure [4,181-185], and been used to map the binding of neutralizing antibodies to viral glycoproteins on intact virions $[4,5,186]$ for example. Using cryo-ET to study filovirus glycoprotein ultrastucture, the large, heavily glycosylated mucin domain, which typically is truncated from constructs used in crystallization, could be localized [187], and glycoprotein organization on the surface of virus particles was readily apparent from reconstructed density maps [162]. Recent reconstructions of Gag structures on the inside of retrovirus particles have yielded striking clarity at $\sim 8 \AA$ resolution, revealing for example helical sub-structures in portions of the Gag lattices $[188,189]$. Gag adopts a repeated lattice organization inside of particles, which helps constrain the individual protein copies while facilitating averaging [180]. While it may be challenging to achieve such resolutions for the more dynamic, heterogeneous surface glycoproteins, the Gag studies highlight what is achievable with sub-tomogram averaging under optimal circumstances with rigorous and thorough processing and analysis.

Single particle analysis, that is typically performed on purified proteins and complexes is now enabling structural biologists to achieve near-atomic resolution of protein assemblies without requiring crystallization of the glycoprotein of interest $[7,77,190,191]$. This approach does not require proteins to be deglycosylated or to have loops truncated, which often are necessary to produce constructs amenable to crystallization. One images fields of proteins flash-frozen in vitreous ice, and reconstructs a 3-dimensional image based upon the individual projection images of the individual particles. Ideally the particles are randomly oriented, providing a thorough sampling of views of the 3-dimensional proteins. In the reconstruction process, it is necessary to determine how the different views relate to each other and to the 3-dimensional model. Fabs bound to proteins in the size range of common viral antigens ( 200-400 kDa) can provide prominent features that aid in the determination of particle orientations from relatively noisy micrographs [192]. Remarkably, by single-particle analysis it is 
becoming possible to resolve significant portions of glycan chain density with the use of state-of-the-art imaging and analysis approaches [7,191].

In some cases, samples may not be amenable to cryo-EM preparation, or one may not require the detailed insights offered by high-resolution structure determination. In these cases, negative-stain EM with single particle analysis can provide valuable information. Here, samples are adsorbed to carbon-coated EM grids and a thin layer of a heavy metal stain coats the specimens. The samples are no longer under native conditions as in cryo-EM, but staining often helps to fix the specimens, providing a high-contrast cast of their structure. When imaging flexible proteins using negative stain EM, adsorption to the carbon substrate, sample dehydration, and stain-protein interactions can potentially deform the objects of interest. Thus, it is useful to validate the negative stain EM models against all available structural information gathered by other methods such as X-ray crystallography.

Nonetheless, negative stain EM with single particle reconstruction has been useful for example in identifying the organization of Ebola GP-antibody complexes from a panel of antibodies comprising the ZMapp antibody cocktail, which is being used to treat the 2014 West Africa outbreak [193]. Epitope surfaces could be localized and general Fab orientations and approach angles were clearly evident in the low-resolution structures. Likewise in numerous studies of influenza HA, HCV, Marburg, and Ebola glycoproteins as well as soluble, engineered forms of HIV Env trimers, negative-stain EM has provided valuable models that reveal the epitope surfaces recognized by antibody Fabs as well as the relative orientation of Fab and antigen in the complex [10,149,150,153,193-200].

It is useful to hold some notable caveats in mind when using electron microscopy reconstructions for interpretation of biological data: the beautiful 3-dimensional models are constructed from images of a subset of the total number of particles in a given population, sometimes a small minority of the total particles. Species bias may be present in terms of the particle types or species that favorably position themselves in the EM grid holes or that adsorb to carbon substrates in the case of negative stain EM imaging. In the process of optimizing single particle EM reconstructions, selection of particles that are more similar to each other and improve the resulting reconstruction also winnows the population of particles that are used in composing the final model. Here it is useful to avoid assuming that the end model one obtains necessarily is representative of the population that one started with in a specimen. As classification methods improve, and sense can be made of heterogeneous samples, the strength of cryo-EM in imaging individual particles opens new windows into studying conformational variability and structural dynamics [152]. The reader is also referred to recent discussions that describe the pitfalls and challenges in EM image analysis both in single-particle cryo-EM analysis [201-203] and in cryo-electron tomography [4,181-185].

Cryo-EM has been useful for resolving the internal and external architecture of complex, enveloped viruses, revealing how the many components-glycoproteins, matrix proteins, ribonucleoprotein complexes, and membranes-are integrated into an infectious particle [30-33,204-208]. For some icosahedrally symmetrical particles, such as many of the flaviviruses, cryo-EM is providing resolution to rival crystallography. A $4.4 \AA$ resolution structure of the Venezuela equine encephalitis virus was able to identify novel structural features not observed by crystallography and validate de novo models of the E1, E2 fusion protein complex in an infectious particle [209]. Different serotypes of dengue viruses have also been solved to near-atomic resolution, which were capable of distinguishing isolate specific differences, and identifying structural modifications necessary for viral maturation and pH-dependent fusion [205,206,208].

\section{Conclusions}

Taken together, these reports highlight the diverse application of solution-phase techniques for structural analysis and structure determination, which in combination with known high-resolution data can be used to investigate viral glycoproteins in multiple functional states. HDX-MS, oxidative labeling, SAXS and EM will continue to provide unprecedented insight into the most dynamic stages of the infectious cycles of viruses as few other techniques are capable of probing these states in such 
detail. Additionally, approaches such as single-molecule fluorescence with structure-specific Förster resonance energy transfer labels, while low in specific structural information content offer tremendous insight into dynamics of conformational sampling and enable protein function to be directly observed as has been demonstrated for HIV Env on the surface virus particles [12,14]. In addition, synergy is gained between these and classical methods when information from multiple sources can be combined to generate a far richer, more complete picture of the structure and function of these dynamic, variable and complex viral glycoproteins than any single method alone can provide [210]. Integrative structural biology of viral glycoproteins is thus poised to move from the realm of providing static snapshots of beginning and end states towards shedding light on the dynamic processes and conformational changes that drive their function.

Acknowledgments: The authors were supported by NIH Grants R01-GM099989 (Kelly K. Lee), T32-GM007750 (Natalie K. Garcia), the Hope Barns Fellowship (Natalie K. Garcia), and Bill and Melinda Gates Foundation grants OPP1033102 and OPP1126258 (Kelly K. Lee).

Author Contributions: Natalie K. Garcia and Kelly K. Lee wrote the manuscript.

Conflicts of Interest: The authors declare no conflict of interest.

\section{References}

1. Garcia, N.K.; Guttman, M.; Ebner, J.L.; Lee, K.K. Dynamic Changes during Acid-Induced Activation of Influenza Hemagglutinin. Structure 2015, 23, 665-676. [CrossRef] [PubMed]

2. Guttman, M.; Garcia, N.K.; Cupo, A.; Matsui, T.; Julien, J.P.; Sanders, R.W.; Wilson, I.A.; Moore, J.P.; Lee, K.K. CD4-induced activation in a soluble HIV-1 Env trimer. Structure 2014, 22, 974-984. [CrossRef] [PubMed]

3. Guttman, M.; Cupo, A.; Julien, J.P.; Sanders, R.W.; Wilson, I.A.; Moore, J.P.; Lee, K.K. Antibody potency relates to the ability to recognize the closed, pre-fusion form of HIV Env. Nat. Commun. 2015, 6. [CrossRef] [PubMed]

4. Liu, J.; Bartesaghi, A.; Borgnia, M.J.; Sapiro, G.; Subramaniam, S. Molecular architecture of native HIV-1 gp120 trimers. Nature 2008, 455, 109-113. [CrossRef] [PubMed]

5. Tran, E.E.; Borgnia, M.J.; Kuybeda, O.; Schauder, D.M.; Bartesaghi, A.; Frank, G.A.; Sapiro, G.; Milne, J.L.; Subramaniam, S. Structural mechanism of trimeric HIV-1 envelope glycoprotein activation. PLoS Pathog. 2012, 8, e1002797. [CrossRef] [PubMed]

6. Harris, A.; Borgnia, M.J.; Shi, D.; Bartesaghi, A.; He, H.; Pejchal, R.; Kang, Y.K.; Depetris, R.; Marozsan, A.J.; Sanders, R.W.; et al. Trimeric HIV-1 glycoprotein gp140 immunogens and native HIV-1 envelope glycoproteins display the same closed and open quaternary molecular architectures. Proc. Natl. Acad. Sci. USA 2011, 108, 11440-11445. [CrossRef] [PubMed]

7. Lyumkis, D.; Julien, J.P.; de Val, N.; Cupo, A.; Potter, C.S.; Klasse, P.J.; Burton, D.R.; Sanders, R.W.; Moore, J.P.; Carragher, B.; et al. Cryo-EM structure of a fully glycosylated soluble cleaved HIV-1 envelope trimer. Science 2013, 342, 1484-1490. [CrossRef] [PubMed]

8. Julien, J.P.; Cupo, A.; Sok, D.; Stanfield, R.L.; Lyumkis, D.; Deller, M.C.; Klasse, P.J.; Burton, D.R.; Sanders, R.W.; Moore, J.P.; et al. Crystal structure of a soluble cleaved HIV-1 envelope trimer. Science 2013, 342, 1477-1483. [CrossRef] [PubMed]

9. Depetris, R.S.; Julien, J.P.; Khayat, R.; Lee, J.H.; Pejchal, R.; Katpally, U.; Cocco, N.; Kachare, M.; Massi, E.; David, K.B.; et al. Partial enzymatic deglycosylation preserves the structure of cleaved recombinant HIV-1 envelope glycoprotein trimers. J. Biol. Chem. 2012, 287, 24239-24254. [CrossRef] [PubMed]

10. Sanders, R.W.; Derking, R.; Cupo, A.; Julien, J.P.; Yasmeen, A.; de Val, N.; Kim, H.J.; Blattner, C.; de la Pena, A.T.; Korzun, J.; et al. A next-generation cleaved, soluble HIV-1 Env trimer, BG505 SOSIP.664 gp140, expresses multiple epitopes for broadly neutralizing but not non-neutralizing antibodies. PLoS Pathog. 2013, 9, e1003618. [CrossRef] [PubMed]

11. Ivanovic, T.; Choi, J.L.; Whelan, S.P.; van Oijen, A.M.; Harrison, S.C. Influenza-virus membrane fusion by cooperative fold-back of stochastically induced hemagglutinin intermediates. eLife 2013, 2, e00333. [CrossRef] [PubMed] 
12. Munro, J.B.; Gorman, J.; Ma, X.; Zhou, Z.; Arthos, J.; Burton, D.R.; Koff, W.C.; Courter, J.R.; Smith, A.B., 3rd; Kwong, P.D.; et al. Conformational dynamics of single HIV-1 envelope trimers on the surface of native virions. Science 2014, 346, 759-763. [CrossRef] [PubMed]

13. Costello, D.A.; Whittaker, G.R.; Daniel, S. Variations in pH sensitivity, acid stability, and fusogenicity of three influenza virus H3 subtypes. J. Virol. 2015, 89, 350-360. [CrossRef] [PubMed]

14. Pancera, M.; Zhou, T.; Druz, A.; Georgiev, I.S.; Soto, C.; Gorman, J.; Huang, J.; Acharya, P.; Chuang, G.Y.; Ofek, G.; et al. Structure and immune recognition of trimeric pre-fusion HIV-1 Env. Nature 2014, 514, $455-461$. [CrossRef] [PubMed]

15. Davenport, T.M.; Guttman, M.; Guo, W.; Cleveland, B.; Kahn, M.; Hu, S.L.; Lee, K.K. Isolate-specific differences in the conformational dynamics and antigenicity of HIV-1 gp120. J. Virol. 2013, 87, 10855-10873. [CrossRef] [PubMed]

16. Bale, S.; Dias, J.M.; Fusco, M.L.; Hashiguchi, T.; Wong, A.C.; Liu, T.; Keuhne, A.I.; Li, S.; Woods, V.L., Jr.; Chandran, K.; et al. Structural basis for differential neutralization of ebolaviruses. Viruses 2012, 4, 447-470. [CrossRef] [PubMed]

17. Bale, S.; Liu, T.; Li, S.; Wang, Y.; Abelson, D.; Fusco, M.; Woods, V.L., Jr.; Saphire, E.O. Ebola virus glycoprotein needs an additional trigger, beyond proteolytic priming for membrane fusion. PLoS Negl. Trop. Dis. 2011, 5, e1395. [CrossRef] [PubMed]

18. Wilson, I.A.; Skehel, J.J.; Wiley, D.C. Structure of the haemagglutinin membrane glycoprotein of influenza virus at $3 \AA$ resolution. Nature 1981, 289, 366-373. [CrossRef]

19. Bullough, P.A.; Hughson, F.M.; Skehel, J.J.; Wiley, D.C. Structure of influenza haemagglutinin at the $\mathrm{pH}$ of membrane fusion. Nature 1994, 371,37-43. [CrossRef] [PubMed]

20. Gigant, B.; Barbey-Martin, C.; Bizebard, T.; Fleury, D.; Daniels, R.; Skehel, J.J.; Knossow, M. A neutralizing antibody Fab-influenza haemagglutinin complex with an unprecedented 2:1 stoichiometry: characterization and crystallization. Acta Crystallogr. D Biol. Crystallogr. 2000, 56, 1067-1069. [CrossRef] [PubMed]

21. Knossow, M.; Gaudier, M.; Douglas, A.; Barrere, B.; Bizebard, T.; Barbey, C.; Gigant, B.; Skehel, J.J. Mechanism of neutralization of influenza virus infectivity by antibodies. Virology 2002, 302, 294-298. [CrossRef] [PubMed]

22. Barbey-Martin, C.; Gigant, B.; Bizebard, T.; Calder, L.J.; Wharton, S.A.; Skehel, J.J.; Knossow, M. An antibody that prevents the hemagglutinin low $\mathrm{pH}$ fusogenic transition. Virology 2002, 294, 70-74. [CrossRef] [PubMed]

23. Bizebard, T.; Gigant, B.; Rigolet, P.; Rasmussen, B.; Diat, O.; Bosecke, P.; Wharton, S.A.; Skehel, J.J.; Knossow, M. Structure of influenza virus haemagglutinin complexed with a neutralizing antibody. Nature 1995, 376, 92-94. [CrossRef] [PubMed]

24. Corti, D.; Voss, J.; Gamblin, S.J.; Codoni, G.; Macagno, A.; Jarrossay, D.; Vachieri, S.G.; Pinna, D.; Minola, A.; Vanzetta, F.; et al. A neutralizing antibody selected from plasma cells that binds to group 1 and group 2 influenza A hemagglutinins. Science 2011, 333, 850-856. [CrossRef] [PubMed]

25. Dreyfus, C.; Ekiert, D.C.; Wilson, I.A. Structure of a classical broadly neutralizing stem antibody in complex with a pandemic H2 influenza virus hemagglutinin. J. Virol. 2013, 87, 7149-7154. [CrossRef] [PubMed]

26. Ekiert, D.C.; Friesen, R.H.; Bhabha, G.; Kwaks, T.; Jongeneelen, M.; Yu, W.; Ophorst, C.; Cox, F.; Korse, H.J.; Brandenburg, B.; et al. A highly conserved neutralizing epitope on group 2 influenza A viruses. Science 2011, 333, 843-850. [CrossRef] [PubMed]

27. Ekiert, D.C.; Kashyap, A.K.; Steel, J.; Rubrum, A.; Bhabha, G.; Khayat, R.; Lee, J.H.; Dillon, M.A.; O'Neil, R.E.; Faynboym, A.M.; et al. Cross-neutralization of influenza A viruses mediated by a single antibody loop. Nature 2012, 489, 526-532. [CrossRef] [PubMed]

28. Lee, P.S.; Ohshima, N.; Stanfield, R.L.; Yu, W.L.; Iba, Y.; Okuno, Y.; Kurosawa, Y.; Wilson, I.A. Receptor mimicry by antibody F045-092 facilitates universal binding to the H3 subtype of influenza virus. Nat. Commun. 2014, 5. [CrossRef] [PubMed]

29. Xu, R.; Krause, J.C.; McBride, R.; Paulson, J.C.; Crowe, J.E., Jr.; Wilson, I.A. A recurring motif for antibody recognition of the receptor-binding site of influenza hemagglutinin. Nat. Struct. Mol. Biol. 2013, 20, 363-370. [CrossRef] [PubMed]

30. Harris, A.; Cardone, G.; Winkler, D.C.; Heymann, J.B.; Brecher, M.; White, J.M.; Steven, A.C. Influenza virus pleiomorphy characterized by cryoelectron tomography. Proc. Natl. Acad. Sci. USA 2006, 103, 19123-19127. [CrossRef] [PubMed]

31. Lee, K.K. Architecture of a nascent viral fusion pore. EMBO J. 2010, 29, 1299-1311. [CrossRef] [PubMed] 
32. Fontana, J.; Cardone, G.; Heymann, J.B.; Winkler, D.C.; Steven, A.C. Structural Changes in Influenza Virus at Low pH Characterized by Cryo-Electron Tomography. J. Virol. 2012, 86, 2919-2929. [CrossRef] [PubMed]

33. Fontana, J.; Steven, A.C. At low $\mathrm{pH}$, influenza virus matrix protein M1 undergoes a conformational change prior to dissociating from the membrane. J. Virol. 2013, 87, 5621-5628. [CrossRef] [PubMed]

34. Calder, L.J.; Wasilewski, S.; Berriman, J.A.; Rosenthal, P.B. Structural organization of a filamentous influenza A virus. Proc. Natl. Acad. Sci. USA 2010, 107, 10685-10690. [CrossRef] [PubMed]

35. Carr, C.M.; Kim, P.S. A spring-loaded mechanism for the conformational change of influenza hemagglutinin. Cell 1993, 73, 823-832. [CrossRef]

36. Baker, D.; Agard, D.A. Influenza hemagglutinin: kinetic control of protein function. Structure 1994, 2, 907-910. [CrossRef]

37. Carr, C.M.; Chaudhry, C.; Kim, P.S. Influenza hemagglutinin is spring-loaded by a metastable native conformation. Proc. Natl. Acad. Sci. USA 1997, 94, 14306-14313. [CrossRef] [PubMed]

38. Remeta, D.P.; Krumbiegel, M.; Minetti, C.A.; Puri, A.; Ginsburg, A.; Blumenthal, R. Acid-induced changes in thermal stability and fusion activity of influenza hemagglutinin. Biochemistry 2002, 41, 2044-2054. [CrossRef] [PubMed]

39. Ruigrok, R.W.; Martin, S.R.; Wharton, S.A.; Skehel, J.J.; Bayley, P.M.; Wiley, D.C. Conformational changes in the hemagglutinin of influenza virus which accompany heat-induced fusion of virus with liposomes. Virology 1986, 155, 484-497. [CrossRef]

40. Korte, T.; Ludwig, K.; Krumbiegel, M.; Zirwer, D.; Damaschun, G.; Herrmann, A. Transient changes of the conformation of hemagglutinin of influenza virus at low $\mathrm{pH}$ detected by time-resolved circular dichroism spectroscopy. J. Biol. Chem. 1997, 272, 9764-9770. [PubMed]

41. Korte, T.; Ludwig, K.; Booy, F.P.; Blumenthal, R.; Herrmann, A. Conformational intermediates and fusion activity of influenza virus hemagglutinin. J. Virol. 1999, 73, 4567-4574. [PubMed]

42. Puri, A.; Booy, F.P.; Doms, R.W.; White, J.M.; Blumenthal, R. Conformational changes and fusion activity of influenza virus hemagglutinin of the $\mathrm{H} 2$ and $\mathrm{H} 3$ subtypes: Effects of acid pretreatment. J. Virol. 1990, 64, 3824-3832. [PubMed]

43. Floyd, D.L.; Ragains, J.R.; Skehel, J.J.; Harrison, S.C.; van Oijen, A.M. Single-particle kinetics of influenza virus membrane fusion. Proc. Natl. Acad. Sci. USA 2008, 105, 15382-15387. [CrossRef] [PubMed]

44. Costello, D.A.; Lee, D.W.; Drewes, J.; Vasquez, K.A.; Kisler, K.; Wiesner, U.; Pollack, L.; Whittaker, G.R.; Daniel, S. Influenza virus-membrane fusion triggered by proton uncaging for single particle studies of fusion kinetics. Anal. Chem. 2012, 84, 8480-8489. [CrossRef] [PubMed]

45. Hamilton, B.S.; Whittaker, G.R.; Daniel, S. Influenza virus-mediated membrane fusion: determinants of hemagglutinin fusogenic activity and experimental approaches for assessing virus fusion. Viruses 2012, 4, 1144-1168. [CrossRef] [PubMed]

46. Lakadamyali, M.; Rust, M.J.; Babcock, H.P.; Zhuang, X. Visualizing infection of individual influenza viruses. Proc. Natl. Acad. Sci. USA 2003, 100, 9280-9285. [CrossRef] [PubMed]

47. Rust, M.J.; Lakadamyali, M.; Zhang, F.; Zhuang, X. Assembly of endocytic machinery around individual influenza viruses during viral entry. Nat. Struct. Mol. Biol. 2004, 11, 567-573. [CrossRef] [PubMed]

48. Sullivan, N.; Sun, Y.; Sattentau, Q.; Thali, M.; Wu, D.; Denisova, G.; Gershoni, J.; Robinson, J.; Moore, J.; Sodroski, J. CD4-Induced conformational changes in the human immunodeficiency virus type 1 gp120 glycoprotein: consequences for virus entry and neutralization. J. Virol. 1998, 72, 4694-4703. [PubMed]

49. Kwong, P.D.; Wyatt, R.; Robinson, J.; Sweet, R.W.; Sodroski, J.; Hendrickson, W.A. Structure of an HIV gp120 envelope glycoprotein in complex with the CD4 receptor and a neutralizing human antibody. Nature 1998, 393, 648-659. [PubMed]

50. Wyatt, R.; Kwong, P.D.; Desjardins, E.; Sweet, R.W.; Robinson, J.; Hendrickson, W.A.; Sodroski, J.G. The antigenic structure of the HIV gp120 envelope glycoprotein. Nature 1998, 393, 705-711. [PubMed]

51. Myszka, D.G.; Sweet, R.W.; Hensley, P.; Brigham-Burke, M.; Kwong, P.D.; Hendrickson, W.A.; Wyatt, R.; Sodroski, J.; Doyle, M.L. Energetics of the HIV gp120-CD4 binding reaction. Proc. Natl. Acad. Sci. USA 2000, 97, 9026-9031. [CrossRef] [PubMed]

52. Guttman, M.; Kahn, M.; Garcia, N.K.; Hu, S.L.; Lee, K.K. Solution structure, conformational dynamics, and CD4-induced activation in full-length, glycosylated, monomeric HIV gp120. J. Virol. 2012, 86, 8750-8764. [CrossRef] [PubMed] 
53. Kong, L.; Huang, C.C.; Coales, S.J.; Molnar, K.S.; Skinner, J.; Hamuro, Y.; Kwong, P.D. Local conformational stability of HIV-1 gp120 in unliganded and CD4-bound states as defined by amide hydrogen/deuterium exchange. J. Virol. 2010, 84, 10311-10321. [CrossRef] [PubMed]

54. Paulson, J.C.; Sadler, J.E.; Hill, R.L. Restoration of specific myxovirus receptors to asialoerythrocytes by incorporation of sialic acid with pure sialyltransferases. J. Biol. Chem. 1979, 254, 2120-2124. [PubMed]

55. Matlin, K.S.; Reggio, H.; Helenius, A.; Simons, K. Infectious entry pathway of influenza virus in a canine kidney cell line. J. Cell Biol. 1981, 91, 601-613. [CrossRef] [PubMed]

56. Skehel, J.J.; Wiley, D.C. Receptor binding and membrane fusion in virus entry: the influenza hemagglutinin. Annu. Rev. Biochem. 2000, 69, 531-569. [CrossRef] [PubMed]

57. Wiley, D.C.; Skehel, J.J. The structure and function of the hemagglutinin membrane glycoprotein of influenza virus. Annu. Rev. Biochem. 1987, 56, 365-394. [CrossRef] [PubMed]

58. Sauter, N.K.; Bednarski, M.D.; Wurzburg, B.A.; Hanson, J.E.; Whitesides, G.M.; Skehel, J.J.; Wiley, D.C. Hemagglutinins from two influenza virus variants bind to sialic acid derivatives with millimolar dissociation constants: a 500-MHz proton nuclear magnetic resonance study. Biochemistry 1989, 28, 8388-8396. [CrossRef] [PubMed]

59. Sauter, N.K.; Hanson, J.E.; Glick, G.D.; Brown, J.H.; Crowther, R.L.; Park, S.J.; Skehel, J.J.; Wiley, D.C. Binding of influenza virus hemagglutinin to analogs of its cell-surface receptor, sialic acid: analysis by proton nuclear magnetic resonance spectroscopy and X-ray crystallography. Biochemistry 1992, 31, 9609-9621. [CrossRef] [PubMed]

60. Hanson, J.E.; Sauter, N.K.; Skehel, J.J.; Wiley, D.C. Proton nuclear magnetic resonance studies of the binding of sialosides to intact influenza virus. Virology 1992, 189, 525-533. [CrossRef]

61. Inglis, S.C.; Carroll, A.R.; Lamb, R.A.; Mahy, B.W. Polypeptides specified by the influenza virus genome I. Evidence for eight distinct gene products specified by fowl plague virus. Virology 1976, 74, 489-503. [CrossRef]

62. Ruigrok, R.W.; Andree, P.J.; Hooft van Huysduynen, R.A.; Mellema, J.E. Characterization of three highly purified influenza virus strains by electron microscopy. J. Gen. Virol. 1984, 65, 799-802. [CrossRef] [PubMed]

63. Skehel, J.J.; Bayley, P.M.; Brown, E.B.; Martin, S.R.; Waterfield, M.D.; White, J.M.; Wilson, I.A.; Wiley, D.C. Changes in the conformation of influenza virus hemagglutinin at the $\mathrm{pH}$ optimum of virus-mediated membrane fusion. Proc. Natl. Acad. Sci. USA 1982, 79, 968-972. [CrossRef] [PubMed]

64. Stegmann, T.; White, J.M.; Helenius, A. Intermediates in influenza induced membrane fusion. EMBO J. 1990, 9, 4231-4241. [PubMed]

65. Ruigrok, R.W.; Wrigley, N.G.; Calder, L.J.; Cusack, S.; Wharton, S.A.; Brown, E.B.; Skehel, J.J. Electron microscopy of the low pH structure of influenza virus haemagglutinin. EMBO J. 1986, 5, 41-49. [PubMed]

66. Daniels, P.S.; Jeffries, S.; Yates, P.; Schild, G.C.; Rogers, G.N.; Paulson, J.C.; Wharton, S.A.; Douglas, A.R.; Skehel, J.J.; Wiley, D.C. The receptor-binding and membrane-fusion properties of influenza virus variants selected using anti-haemagglutinin monoclonal antibodies. EMBO J. 1987, 6, 1459-1465. [PubMed]

67. Weissenhorn, W.; Dessen, A.; Harrison, S.C.; Skehel, J.J.; Wiley, D.C. Atomic structure of the ectodomain from HIV-1 gp41. Nature 1997, 387, 426-430. [CrossRef] [PubMed]

68. Chen, J.; Skehel, J.J.; Wiley, D.C. N- and C-terminal residues combine in the fusion-pH influenza hemagglutinin $\mathrm{HA}(2)$ subunit to form an $\mathrm{N}$ cap that terminates the triple-stranded coiled coil. Proc. Natl. Acad. Sci. USA 1999, 96, 8967-8972. [CrossRef] [PubMed]

69. $\mathrm{Xu}, \mathrm{R}$; Wilson, I.A. Structural characterization of an early fusion intermediate of influenza virus hemagglutinin. J. Virol. 2011, 85, 5172-5182. [CrossRef] [PubMed]

70. Leikina, E.; Ramos, C.; Markovic, I.; Zimmerberg, J.; Chernomordik, L.V. Reversible stages of the low-pH-triggered conformational change in influenza virus hemagglutinin. EMBO J. 2002, 21, 5701-5710. [CrossRef] [PubMed]

71. Krumbiegel, M.; Herrmann, A.; Blumenthal, R. Kinetics of the low $\mathrm{pH}$-induced conformational changes and fusogenic activity of influenza hemagglutinin. Biophys. J. 1994, 67(6), 2355-2360. [CrossRef]

72. McLellan, J.S.; Chen, M.; Joyce, M.G.; Sastry, M.; Stewart-Jones, G.B.; Yang, Y.; Zhang, B.; Chen, L.; Srivatsan, S.; Zheng, A.; et al. Structure-based design of a fusion glycoprotein vaccine for respiratory syncytial virus. Science 2013, 342, 592-598. [CrossRef] [PubMed] 
73. Welch, B.D.; Liu, Y.; Kors, C.A.; Leser, G.P.; Jardetzky, T.S.; Lamb, R.A. Structure of the cleavage-activated prefusion form of the parainfluenza virus 5 fusion protein. Proc. Natl. Acad. Sci. USA 2012, 109, 16672-16677. [CrossRef] [PubMed]

74. Yin, H.S.; Wen, X.; Paterson, R.G.; Lamb, R.A.; Jardetzky, T.S. Structure of the parainfluenza virus 5 F protein in its metastable, prefusion conformation. Nature 2006, 439, 38-44. [CrossRef] [PubMed]

75. Dias, J.M.; Kuehne, A.I.; Abelson, D.M.; Bale, S.; Wong, A.C.; Halfmann, P.; Muhammad, M.A.; Fusco, M.L.; Zak, S.E.; Kang, E.; et al. A shared structural solution for neutralizing ebolaviruses. Nat. Struct. Mol. Biol. 2011, 18, 1424-1427. [CrossRef] [PubMed]

76. Lee, J.E.; Fusco, M.L.; Hessell, A.J.; Oswald, W.B.; Burton, D.R.; Saphire, E.O. Structure of the Ebola virus glycoprotein bound to an antibody from a human survivor. Nature 2008, 454, 177-182. [CrossRef] [PubMed]

77. Lee, J.H.; Leaman, D.P.; Kim, A.S.; Torrents de la Pena, A.; Sliepen, K.; Yasmeen, A.; Derking, R.; Ramos, A.; de Taeye, S.W.; Ozorowski, G.; et al. Antibodies to a conformational epitope on gp41 neutralize HIV-1 by destabilizing the Env spike. Nat. Commun. 2015, 6. [CrossRef] [PubMed]

78. Hughson, F.M. Enveloped viruses: A common mode of membrane fusion? Curr. Biol. 1997, 7, R565-R569. [CrossRef]

79. Malashkevich, V.N.; Schneider, B.J.; McNally, M.L.; Milhollen, M.A.; Pang, J.X.; Kim, P.S. Core structure of the envelope glycoprotein GP2 from Ebola virus at 1.9- ̊ resolution. Proc. Natl. Acad. Sci. USA 1999, 96, 2662-2667. [CrossRef] [PubMed]

80. Chan, D.C.; Fass, D.; Berger, J.M.; Kim, P.S. Core structure of gp41 from the HIV envelope glycoprotein. Cell 1997, 89, 263-273. [CrossRef]

81. Weissenhorn, W.; Carfi, A.; Lee, K.H.; Skehel, J.J.; Wiley, D.C. Crystal structure of the Ebola virus membrane fusion subunit, GP2, from the envelope glycoprotein ectodomain. Mol. Cell 1998, 2, 605-616. [CrossRef]

82. Konermann, L.; Vahidi, S.; Sowole, M.A. Mass spectrometry methods for studying structure and dynamics of biological macromolecules. Anal. Chem. 2014, 86, 213-232. [CrossRef] [PubMed]

83. Orban, T.; Gupta, S.; Palczewski, K.; Chance, M.R. Visualizing water molecules in transmembrane proteins using radiolytic labeling methods. Biochemistry 2010, 49, 827-834. [CrossRef] [PubMed]

84. Lim, X.X.; Chandramohan, A.; Anand, G.S. Temperature-dependent Conformational Dynamics in Whole Dengue Viral Particles by Hydrogen/Deuterium Exchange Mass Spectrometry. In Proceedings of the $63^{\text {rd }}$ American Society for Mass spectrometry, St. Louis, MO, USA, 31 May-4 June 2015.

85. Xu, G.; Chance, M.R. Radiolytic modification and reactivity of amino acid residues serving as structural probes for protein footprinting. Anal. Chem. 2005, 77, 4549-4555. [CrossRef] [PubMed]

86. Konermann, L.; Pan, Y. Exploring membrane protein structural features by oxidative labeling and mass spectrometry. Exp. Rev. Proteom. 2012, 9, 497-504. [CrossRef] [PubMed]

87. Gau, B.C.; Sharp, J.S.; Rempel, D.L.; Gross, M.L. Fast photochemical oxidation of protein footprints faster than protein unfolding. Anal. Chem. 2009, 81, 6563-6571. [CrossRef] [PubMed]

88. Iacob, R.E.; Murphy, J.P., 3rd; Engen, J.R. Ion mobility adds an additional dimension to mass spectrometric analysis of solution-phase hydrogen/deuterium exchange. Rapid Commun. Mass Spectrom. 2008, 22, 2898-2904. [CrossRef] [PubMed]

89. Englander, S.W. Hydrogen exchange and mass spectrometry: A historical perspective. J Am Soc Mass Spectrom 2006, 17, 1481-1489. [CrossRef] [PubMed]

90. Kiselar, J.G.; Chance, M.R. Future directions of structural mass spectrometry using hydroxyl radical footprinting. J. Mass Spectrom. 2010, 45, 1373-1382. [CrossRef] [PubMed]

91. Coales, S.J.; Tuske, S.J.; Tomasso, J.C.; Hamuro, Y. Epitope mapping by amide hydrogen/deuterium exchange coupled with immobilization of antibody, on-line proteolysis, liquid chromatography and mass spectrometry. Rapid Commun. Mass Spectrom. 2009, 23, 639-647. [CrossRef] [PubMed]

92. Jones, L.M.; J, B.S.; J, A.C.; Gross, M.L. Fast photochemical oxidation of proteins for epitope mapping. Anal. Chem. 2011, 83, 7657-7661. [CrossRef] [PubMed]

93. Marcsisin, S.R.; Engen, J.R. Hydrogen exchange mass spectrometry: What is it and what can it tell us? Anal. Bioanal. Chem. 2010, 397, 967-972. [CrossRef] [PubMed]

94. Hamuro, Y.; Coales, S.J.; Molnar, K.S.; Tuske, S.J.; Morrow, J.A. Specificity of immobilized porcine pepsin in H/D exchange compatible conditions. Rapid Commun. Mass Spectrom. 2008, 22, 1041-1046. [CrossRef] [PubMed] 
95. Syka, J.E.; Coon, J.J.; Schroeder, M.J.; Shabanowitz, J.; Hunt, D.F. Peptide and protein sequence analysis by electron transfer dissociation mass spectrometry. Proc. Natl. Acad. Sci. USA 2004, 101, 9528-9533. [CrossRef] [PubMed]

96. Rand, K.D.; Pringle, S.D.; Morris, M.; Brown, J.M. Site-specific analysis of gas-phase hydrogen/deuterium exchange of peptides and proteins by electron transfer dissociation. Anal. Chem. 2012, 84, 1931-1940. [CrossRef] [PubMed]

97. Rand, K.D.; Zehl, M.; Jensen, O.N.; Jorgensen, T.J. Protein hydrogen exchange measured at single-residue resolution by electron transfer dissociation mass spectrometry. Anal. Chem. 2009, 81, 5577-5584. [CrossRef] [PubMed]

98. Zhang, H.M.; Kazazic, S.; Schaub, T.M.; Tipton, J.D.; Emmett, M.R.; Marshall, A.G. Enhanced digestion efficiency, peptide ionization efficiency, and sequence resolution for protein hydrogen/deuterium exchange monitored by Fourier transform ion cyclotron resonance mass spectrometry. Anal. Chem. 2008, 80, 9034-9041. [CrossRef] [PubMed]

99. Kadek, A.; Mrazek, H.; Halada, P.; Rey, M.; Schriemer, D.C.; Man, P. Aspartic protease nepenthesin-1 as a tool for digestion in hydrogen/deuterium exchange mass spectrometry. Anal. Chem. 2014, 86, 4287-4294. [CrossRef] [PubMed]

100. Huang, R.Y.; Hudgens, J.W. Effects of desialylation on human alpha1-acid glycoprotein-ligand interactions. Biochemistry 2013, 52, 7127-7136. [CrossRef] [PubMed]

101. Houde, D.; Arndt, J.; Domeier, W.; Berkowitz, S.; Engen, J.R. Characterization of IgG1 Conformation and Conformational Dynamics by Hydrogen/Deuterium Exchange Mass Spectrometry. Anal. Chem. 2009, 81, 2644-2651. [CrossRef] [PubMed]

102. Bai, Y.; Milne, J.S.; Mayne, L.; Englander, S.W. Primary structure effects on peptide group hydrogen exchange. Proteins 1993, 17, 75-86. [CrossRef] [PubMed]

103. DuBois, R.M.; Zaraket, H.; Reddivari, M.; Heath, R.J.; White, S.W.; Russell, C.J. Acid stability of the hemagglutinin protein regulates H5N1 influenza virus pathogenicity. PLoS Pathog. 2011, 7, e1002398. [CrossRef] [PubMed]

104. White, J.M.; Wilson, I.A. Anti-peptide antibodies detect steps in a protein conformational change: Low-pH activation of the influenza virus hemagglutinin. J. Cell Biol. 1987, 105, 2887-2896. [CrossRef] [PubMed]

105. Kemble, G.W.; Bodian, D.L.; Rose, J.; Wilson, I.A.; White, J.M. Intermonomer disulfide bonds impair the fusion activity of influenza virus hemagglutinin. J. Virol. 1992, 66, 4940-4950. [PubMed]

106. Galloway, S.E.; Reed, M.L.; Russell, C.J.; Steinhauer, D.A. Influenza HA subtypes demonstrate divergent phenotypes for cleavage activation and $\mathrm{pH}$ of fusion: Implications for host range and adaptation. PLoS Pathog. 2013, 9, e1003151. [CrossRef] [PubMed]

107. Byrd-Leotis, L.; Galloway, S.E.; Agbogu, E.; Steinhauer, D.A. Influenza hemagglutinin (HA) stem region mutations that stabilize or destabilize the structure of multiple HA subtypes. J. Virol. 2015, 89, 4504-4516. [CrossRef] [PubMed]

108. Kwong, P.D.; Wyatt, R.; Majeed, S.; Robinson, J.; Sweet, R.W.; Sodroski, J.; Hendrickson, W.A. Structures of HIV-1 gp120 envelope glycoproteins from laboratory-adapted and primary isolates. Structure 2000, 8 , 1329-1339. [CrossRef]

109. Khayat, R.; Lee, J.H.; Julien, J.P.; Cupo, A.; Klasse, P.J.; Sanders, R.W.; Moore, J.P.; Wilson, I.A.; Ward, A.B. Structural Characterization of Cleaved, Soluble HIV-1 Envelope Glycoprotein Trimers. J. Virol. 2013, 87, 9865-9872. [CrossRef] [PubMed]

110. Khan, A.G.; Whidby, J.; Miller, M.T.; Scarborough, H.; Zatorski, A.V.; Cygan, A.; Price, A.A.; Yost, S.A.; Bohannon, C.D.; Jacob, J.; et al. Structure of the core ectodomain of the hepatitis $C$ virus envelope glycoprotein 2. Nature 2014, 509, 381-384. [CrossRef] [PubMed]

111. Ciferri, C.; Chandramouli, S.; Donnarumma, D.; Nikitin, P.A.; Cianfrocco, M.A.; Gerrein, R.; Feire, A.L.; Barnett, S.W.; Lilja, A.E.; Rappuoli, R.; et al. Structural and biochemical studies of HCMV gH/gL/gO and Pentamer reveal mutually exclusive cell entry complexes. Proc. Natl. Acad. Sci. USA 2015, 112, 1767-1772. [CrossRef] [PubMed]

112. Weis, D.D.; Wales, T.E.; Engen, J.R.; Hotchko, M.; Ten Eyck, L.F. Identification and characterization of EX1 kinetics in H/D exchange mass spectrometry by peak width analysis. J. Am. Soc. Mass Spectrom 2006, 17, 1498-1509. [CrossRef] [PubMed] 
113. Guttman, M.; Lee, K.K. A functional interaction between gp41 and gp120 is observed for monomeric but not oligomeric, uncleaved HIV-1 Env gp140. J. Virol. 2013, 87, 11462-11475. [CrossRef] [PubMed]

114. Wei, H.; Mo, J.; Tao, L.; Russell, R.J.; Tymiak, A.A.; Chen, G.; Iacob, R.E.; Engen, J.R. Hydrogen/deuterium exchange mass spectrometry for probing higher order structure of protein therapeutics: Methodology and applications. Drug Discov. Today 2014, 19, 95-102. [CrossRef] [PubMed]

115. Visser, J.; Feuerstein, I.; Stangler, T.; Schmiederer, T.; Fritsch, C.; Schiestl, M. Physicochemical and functional comparability between the proposed biosimilar rituximab GP2013 and originator rituximab. BioDrugs 2013, 27, 495-507. [CrossRef] [PubMed]

116. Houde, D.; Berkowitz, S.A.; Engen, J.R. The utility of hydrogen/deuterium exchange mass spectrometry in biopharmaceutical comparability studies. J. Pharm. Sci. 2011, 100, 2071-2086. [CrossRef] [PubMed]

117. Kiselar, J.G.; Maleknia, S.D.; Sullivan, M.; Downard, K.M.; Chance, M.R. Hydroxyl radical probe of protein surfaces using synchrotron X-ray radiolysis and mass spectrometry. Int. J. Radiat. Biol. 2002, 78, 101-114. [CrossRef] [PubMed]

118. Maleknia, S.D.; Brenowitz, M.; Chance, M.R. Millisecond radiolytic modification of peptides by synchrotron X-rays identified by mass spectrometry. Anal. Chem. 1999, 71, 3965-3973. [CrossRef] [PubMed]

119. Hambly, D.M.; Gross, M.L. Laser flash photolysis of hydrogen peroxide to oxidize protein solvent-accessible residues on the microsecond timescale. J. Am. Soc. Mass Spectrom. 2005, 16, 2057-2063. [CrossRef] [PubMed]

120. Xu, G.; Chance, M.R. Hydroxyl radical-mediated modification of proteins as probes for structural proteomics. Chem. Rev. 2007, 107, 3514-3543. [CrossRef] [PubMed]

121. Chen, J.; Rempel, D.L.; Gau, B.C.; Gross, M.L. Fast photochemical oxidation of proteins and mass spectrometry follow submillisecond protein folding at the amino-acid level. J. Am. Chem. Soc. 2012, 134, 18724-18731. [CrossRef] [PubMed]

122. Wang, L.; Qin, Y.; Ilchenko, S.; Bohon, J.; Shi, W.; Cho, M.W.; Takamoto, K.; Chance, M.R. Structural analysis of a highly glycosylated and unliganded gp120-based antigen using mass spectrometry. Biochemistry 2010, 49, 9032-9045. [CrossRef] [PubMed]

123. Li, X.; Sharp, J.S. Structural Analysis of HIV-1 gp120 and its Complex with Neutralizing Immunoglobulin G1 b12 using Hydroxyl Radical Protein Footprinting. In Proceedings of the $62^{\text {nd }}$ American Society for Mass Spectrometry Conference, Baltimore, MD, USA, 15-19 June 2014.

124. Poor, T.A.; Jones, L.M.; Sood, A.; Leser, G.P.; Plasencia, M.D.; Rempel, D.L.; Jardetzky, T.S.; Woods, R.J.; Gross, M.L.; Lamb, R.A. Probing the paramyxovirus fusion (F) protein-refolding event from pre- to postfusion by oxidative footprinting. Proc. Natl. Acad. Sci. USA 2014, 111, E2596-E2605. [CrossRef] [PubMed]

125. Xu, G.; Kiselar, J.; He, Q.; Chance, M.R. Secondary reactions and strategies to improve quantitative protein footprinting. Anal. Chem. 2005, 77, 3029-3037. [CrossRef] [PubMed]

126. Xie, B.; Sharp, J.S. Hydroxyl radical dosimetry for high flux hydroxyl radical protein footprinting applications using a simple optical detection method. Anal. Chem. 2015, 87, 10719-10723. [CrossRef] [PubMed]

127. Putnam, C.D.; Hammel, M.; Hura, G.L.; Tainer, J.A. X-ray solution scattering (SAXS) combined with crystallography and computation: Defining accurate macromolecular structures, conformations and assemblies in solution. Q. Rev. Biophys. 2007, 40, 191-285. [CrossRef] [PubMed]

128. Jacques, D.A.; Trewhella, J. Small-angle scattering for structural biology-Expanding the frontier while avoiding the pitfalls. Protein Sci. 2010, 19, 642-657. [CrossRef] [PubMed]

129. Mylonas, E.; Svergun, D.I. Accuracy of molecular mass determination of proteins in solution by small-angle X-ray scattering. J. Appl. Crystallogr. 2007, 40, S245-S249. [CrossRef]

130. Fischer, H.; de Oliveira Neto, M.; Napolitano, H.B.; Craievich, A.F.; Polikarpov, I. The molecular weight of proteins in solution can be determined from a single SAXS measurement on a relative scale. J. Appl. Cryst. 2010, 43, 101-109. [CrossRef]

131. Petoukhov, M.V.; Svergun, D.I. Analysis of X-ray and neutron scattering from biomolecular solutions. Curr. Opin. Struc. Biol. 2007, 562-571. [CrossRef] [PubMed]

132. Guttman, M.; Weinkam, P.; Sali, A.; Lee, K.K. All-atom ensemble modeling to analyze small-angle X-ray scattering of glycosylated proteins. Structure 2013, 21, 321-331. [CrossRef] [PubMed]

133. Hammel, M.; Kriechbaum, M.; Gries, A.; Kostner, G.M.; Laggner, P.; Prassl, R. Solution structure of human and bovine $\beta(2)$-glycoprotein I revealed by small-angle X-ray scattering. J. Mol. Biol. 2002, 321, 85-97. [CrossRef] 
134. Svergun, D.I. Restoring low resolution structure of biological macromolecules from solution scattering using simulated annealing. Biophys. J. 1999, 76, 2879-2886. [CrossRef]

135. Svergun, D.I.; Koch, M.H. Advances in structure analysis using small-angle scattering in solution. mboxemphCurr. Opin. Struct. Biol. 2002, 12, 654-660. [CrossRef]

136. Svergun, D.I.; Petoukhov, M.V.; Koch, M.H. Determination of domain structure of proteins from X-ray solution scattering. Biophys. J. 2001, 80, 2946-2953. [CrossRef]

137. Forster, F.; Webb, B.; Krukenberg, K.A.; Tsuruta, H.; Agard, D.A.; Sali, A. Integration of small-angle X-ray scattering data into structural modeling of proteins and their assemblies. J. Mol. Biol. 2008, 382, 1089-1106. [CrossRef] [PubMed]

138. Petoukhov, M.V.; Eady, N.A.J.; Brown, K.A.; Svergun, D.I. Addition of missing loops and domains to protein models by X-ray solution scattering. Biophys. J. 2002, 83, 3113-3125. [CrossRef]

139. Hammel, M. Validation of macromolecular flexibility in solution by small-angle X-ray scattering (SAXS). Eur. Biophys. J. 2012, 41, 789-799. [CrossRef] [PubMed]

140. Weinkam, P.; Pons, J.; Sali, A. Structure-based model of allostery predicts coupling between distant sites. Proc. Natl. Acad. Sci. USA 2012, 109, 4875-4880. [CrossRef] [PubMed]

141. Schneidman-Duhovny, D.; Hammel, M.; Sali, A. FoXS: A web server for rapid computation and fitting of SAXS profiles. Nucleic Acids Res. 2010, 38, W540-W544. [CrossRef] [PubMed]

142. Garg, R.; Anguita, J.; Krueger, J.K. Binding of full-length HIV-1 gp120 to CD4 induces structural reorientation around the gp120 core. Biophys. J. 2006, 91, L69-L71.

143. Zheng, Y.; Doerschuk, P.C.; Johnson, J.E. Determination of three-dimensional low-resolution viral structure from solution X-ray scattering data. Biophys. J. 1995, 69, 619-639. [CrossRef]

144. Perez, J.; Defrenne, S.; Witz, J.; Vachette, P. Detection and characterization of an intermediate conformation during the divalent ion-dependent swelling of tomato bushy stunt virus. Cell Mol. Biol. 2000, 46, 937-948. [PubMed]

145. Canady, M.A.; Tsuruta, H.; Johnson, J.E. Analysis of rapid, large-scale protein quaternary structural changes: time-resolved X-ray solution scattering of Nudaurelia capensis omega virus (NomegaV) maturation. J. Mol. Biol. 2001, 311, 803-814. [CrossRef] [PubMed]

146. Aramayo, R.; Merigoux, C.; Larquet, E.; Bron, P.; Perez, J.; Dumas, C.; Vachette, P.; Boisset, N. Divalent ion-dependent swelling of tomato bushy stunt virus: A multi-approach study. Biochim. Biophys. Acta. 2005, 1724, 345-354. [CrossRef] [PubMed]

147. Lee, K.K.; Tsuruta, H.; Hendrix, R.W.; Duda, R.L.; Johnson, J.E. Cooperative reorganization of a 420 subunit virus capsid. J. Mol. Biol. 2005, 352, 723-735. [CrossRef] [PubMed]

148. Kler, S.; Asor, R.; Li, C.; Ginsburg, A.; Harries, D.; Oppenheim, A.; Zlotnick, A.; Raviv, U. RNA encapsidation by SV40-derived nanoparticles follows a rapid two-state mechanism. J. Am. Chem. Soc. 2012, 134, 8823-8830. [CrossRef] [PubMed]

149. Hashiguchi, T.; Fusco, M.L.; Bornholdt, Z.A.; Lee, J.E.; Flyak, A.I.; Matsuoka, R.; Kohda, D.; Yanagi, Y.; Hammel, M.; Crowe, J.E., Jr.; Saphire, E.O. Structural basis for Marburg virus neutralization by a cross-reactive human antibody. Cell 2015, 160, 904-912. [CrossRef] [PubMed]

150. Julien, J.P.; Lee, J.H.; Cupo, A.; Murin, C.D.; Derking, R.; Hoffenberg, S.; Caulfield, M.J.; King, C.R.; Marozsan, A.J.; Klasse, P.J.; et al. Asymmetric recognition of the HIV-1 trimer by broadly neutralizing antibody PG9. Proc. Natl. Acad. Sci. USA 2013, 110, 4351-4356. [CrossRef] [PubMed]

151. Leschziner, A.E.; Nogales, E. Visualizing flexibility at molecular resolution: analysis of heterogeneity in single-particle electron microscopy reconstructions. Annu. Rev. Biophys. Biomol. Struct. 2007, 36, 43-62. [CrossRef] [PubMed]

152. Elmlund, D.; Elmlund, H. Cryogenic electron microscopy and single-particle analysis. Annu. Rev. Biochem. 2015, 84, 499-517. [CrossRef] [PubMed]

153. Ward, A.B.; Wilson, I.A. Insights into the trimeric HIV-1 envelope glycoprotein structure. Trends Biochem. Sci. 2015, 40, 101-107. [CrossRef] [PubMed]

154. Lucic, V.; Forster, F.; Baumeister, W. Structural studies by electron tomography: From cells to molecules. Annu. Rev. Biochem. 2005, 74, 833-865. [CrossRef] [PubMed]

155. Subramaniam, S.; Bartesaghi, A.; Liu, J.; Bennett, A.E.; Sougrat, R. Electron tomography of viruses. Curr. Opin. Struct. Biol. 2007, 17, 596-602. [CrossRef] [PubMed] 
156. Grunewald, K.; Cyrklaff, M. Structure of complex viruses and virus-infected cells by electron cryo tomography. Curr. Opin. Microbiol. 2006, 9, 437-442. [CrossRef] [PubMed]

157. Grunewald, K.; Desai, P.; Winkler, D.C.; Heymann, J.B.; Belnap, D.M.; Baumeister, W.; Steven, A.C. Three-dimensional structure of herpes simplex virus from cryo-electron tomography. Science 2003, 302, 1396-1398. [CrossRef] [PubMed]

158. Cyrklaff, M.; Risco, C.; Fernandez, J.J.; Jimenez, M.V.; Esteban, M.; Baumeister, W.; Carrascosa, J.L. Cryo-electron tomography of vaccinia virus. Proc. Natl. Acad. Sci. USA 2005, 102, 2772-2777. [CrossRef] [PubMed]

159. Barcena, M.; Oostergetel, G.T.; Bartelink, W.; Faas, F.G.; Verkleij, A.; Rottier, P.J.; Koster, A.J.; Bosch, B.J. Cryo-electron tomography of mouse hepatitis virus: Insights into the structure of the coronavirion. Proc. Natl. Acad. Sci. USA 2009, 106, 582-587. [CrossRef] [PubMed]

160. Loney, C.; Mottet-Osman, G.; Roux, L.; Bhella, D. Paramyxovirus ultrastructure and genome packaging: cryo-electron tomography of sendai virus. J. Virol. 2009, 83, 8191-8197. [CrossRef] [PubMed]

161. Guichard, P.; Krell, T.; Chevalier, M.; Vaysse, C.; Adam, O.; Ronzon, F.; Marco, S. Three dimensional morphology of rabies virus studied by cryo-electron tomography. J. Struct. Biol. 2011, 176, 32-40. [CrossRef] [PubMed]

162. Beniac, D.R.; Melito, P.L.; Devarennes, S.L.; Hiebert, S.L.; Rabb, M.J.; Lamboo, L.L.; Jones, S.M.; Booth, T.F. The organisation of Ebola virus reveals a capacity for extensive, modular polyploidy. PloS ONE 2012, 7, e29608. [CrossRef] [PubMed]

163. Catanese, M.T.; Uryu, K.; Kopp, M.; Edwards, T.J.; Andrus, L.; Rice, W.J.; Silvestry, M.; Kuhn, R.J.; Rice, C.M. Ultrastructural analysis of hepatitis C virus particles. Proc. Natl. Acad. Sci. USA 2013, 110, 9505-9510. [CrossRef] [PubMed]

164. Liljeroos, L.; Krzyzaniak, M.A.; Helenius, A.; Butcher, S.J. Architecture of respiratory syncytial virus revealed by electron cryotomography. Proc. Natl. Acad. Sci. USA 2013, 110, 11133-11138. [CrossRef] [PubMed]

165. Kiss, G.; Holl, J.M.; Williams, G.M.; Alonas, E.; Vanover, D.; Lifland, A.W.; Gudheti, M.; Guerrero-Ferreira, R.C.; Nair, V.; Yi, H.; et al. Structural analysis of respiratory syncytial virus reveals the position of M2-1 between the matrix protein and the ribonucleoprotein complex. J. Virol. 2014, 88, 7602-7617. [CrossRef] [PubMed]

166. Liljeroos, L.; Huiskonen, J.T.; Ora, A.; Susi, P.; Butcher, S.J. Electron cryotomography of measles virus reveals how matrix protein coats the ribonucleocapsid within intact virions. Proc. Natl. Acad. Sci. USA 2011, 108, 18085-18090. [CrossRef] [PubMed]

167. Battisti, A.J.; Yoder, J.D.; Plevka, P.; Winkler, D.C.; Prasad, V.M.; Kuhn, R.J.; Frey, T.K.; Steven, A.C.; Rossmann, M.G. Cryo-electron tomography of rubella virus. J. Virol. 2012, 86, 11078-11085. [CrossRef] [PubMed]

168. Libersou, S.; Albertini, A.A.; Ouldali, M.; Maury, V.; Maheu, C.; Raux, H.; de Haas, F.; Roche, S.; Gaudin, Y.; Lepault, J. Distinct structural rearrangements of the VSV glycoprotein drive membrane fusion. J. Cell Biol. 191, 199-210. [CrossRef] [PubMed]

169. Cao, S.; Zhang, W. Characterization of an early-stage fusion intermediate of Sindbis virus using cryoelectron microscopy. Proc. Natl. Acad. Sci. USA 2013, 110, 13362-13367. [CrossRef] [PubMed]

170. Maurer, U.E.; Sodeik, B.; Grunewald, K. Native 3D intermediates of membrane fusion in herpes simplex virus 1 entry. Proc. Natl. Acad. Sci. USA 2008, 105, 10559-10564. [CrossRef] [PubMed]

171. Bharat, T.A.; Riches, J.D.; Kolesnikova, L.; Welsch, S.; Krahling, V.; Davey, N.; Parsy, M.L.; Becker, S.; Briggs, J.A. Cryo-electron tomography of Marburg virus particles and their morphogenesis within infected cells. PLoS Biol. 2011, 9, e1001196. [CrossRef] [PubMed]

172. Vijayakrishnan, S.; Loney, C.; Jackson, D.; Suphamungmee, W.; Rixon, F.J.; Bhella, D. Cryotomography of budding influenza A virus reveals filaments with diverse morphologies that mostly do not bear a genome at their distal end. PLoS Pathog. 2013, 9, e1003413. [CrossRef] [PubMed]

173. Carlson, L.A.; Briggs, J.A.; Glass, B.; Riches, J.D.; Simon, M.N.; Johnson, M.C.; Muller, B.; Grunewald, K.; Krausslich, H.G. Three-dimensional analysis of budding sites and released virus suggests a revised model for HIV-1 morphogenesis. Cell Host Microbe 2008, 4, 592-599. [CrossRef] [PubMed]

174. De Marco, A.; Muller, B.; Glass, B.; Riches, J.D.; Krausslich, H.G.; Briggs, J.A. Structural analysis of HIV-1 maturation using cryo-electron tomography. PLoS Pathog. 2010, 6, e1001215. [CrossRef] [PubMed] 
175. Plevka, P.; Battisti, A.J.; Junjhon, J.; Winkler, D.C.; Holdaway, H.A.; Keelapang, P.; Sittisombut, N.; Kuhn, R.J.; Steven, A.C.; Rossmann, M.G. Maturation of flaviviruses starts from one or more icosahedrally independent nucleation centres. EMBO Rep. 2011, 12, 602-606. [CrossRef] [PubMed]

176. Plevka, P.; Battisti, A.J.; Sheng, J.; Rossmann, M.G. Mechanism for maturation-related reorganization of flavivirus glycoproteins. J. Struct. Biol. 2014, 185, 27-31. [CrossRef] [PubMed]

177. Chlanda, P.; Schraidt, O.; Kummer, S.; Riches, J.; Oberwinkler, H.; Prinz, S.; Krausslich, H.G.; Briggs, J.A. Structural Analysis of the Roles of Influenza A Virus Membrane-Associated Proteins in Assembly and Morphology. J. Virol. 2015, 89, 8957-8966. [CrossRef] [PubMed]

178. Gui, L.; Jurgens, E.M.; Ebner, J.L.; Porotto, M.; Moscona, A.; Lee, K.K. Electron tomography imaging of surface glycoproteins on human parainfluenza virus 3: Association of receptor binding and fusion proteins before receptor engagement. mBio 2015, 6, e02393-14. [CrossRef] [PubMed]

179. Gruenke, J.A.; Armstrong, R.T.; Newcomb, W.W.; Brown, J.C.; White, J.M. New insights into the spring-loaded conformational change of influenza virus hemagglutinin. J. Virol. 2002, 76, 4456-4466. [CrossRef] [PubMed]

180. Briggs, J.A. Structural biology in situ-the potential of subtomogram averaging. Curr. Opin. Struct. Biol. 2013, 23, 261-267. [CrossRef] [PubMed]

181. Zhu, P.; Chertova, E.; Bess, J., Jr.; Lifson, J.D.; Arthur, L.O.; Liu, J.; Taylor, K.A.; Roux, K.H. Electron tomography analysis of envelope glycoprotein trimers on HIV and simian immunodeficiency virus virions. Proc. Natl. Acad. Sci. USA 2003, 100, 15812-15817. [CrossRef] [PubMed]

182. Forster, F.; Medalia, O.; Zauberman, N.; Baumeister, W.; Fass, D. Retrovirus envelope protein complex structure in situ studied by cryo-electron tomography. Proc. Natl. Acad. Sci. USA 2005, 102, 4729-4734. [CrossRef] [PubMed]

183. Zanetti, G.; Briggs, J.A.; Grunewald, K.; Sattentau, Q.J.; Fuller, S.D. Cryo-electron tomographic structure of an immunodeficiency virus envelope complex in situ. PLoS Pathog. 2006, 2, e83. [CrossRef] [PubMed]

184. Zhu, P.; Liu, J.; Bess, J., Jr.; Chertova, E.; Lifson, J.D.; Grise, H.; Ofek, G.A.; Taylor, K.A.; Roux, K.H. Distribution and three-dimensional structure of AIDS virus envelope spikes. Nature 2006, 441, 847-852. [CrossRef] [PubMed]

185. Subramaniam, S. The SIV surface spike imaged by electron tomography: One leg or three? PLoS Pathog. 2006, 2, e91. [CrossRef] [PubMed]

186. Harris, A.K.; Meyerson, J.R.; Matsuoka, Y.; Kuybeda, O.; Moran, A.; Bliss, D.; Das, S.R.; Yewdell, J.W.; Sapiro, G.; Subbarao, K.; Subramaniam, S. Structure and accessibility of HA trimers on intact 2009 H1N1 pandemic influenza virus to stem region-specific neutralizing antibodies. Proc. Natl. Acad. Sci. USA 2013, 110, 4592-4597. [CrossRef] [PubMed]

187. Tran, E.E.; Simmons, J.A.; Bartesaghi, A.; Shoemaker, C.J.; Nelson, E.; White, J.M.; Subramaniam, S. Spatial localization of the Ebola virus glycoprotein mucin-like domain determined by cryo-electron tomography. J. Virol. 2014, 88, 10958-10962. [CrossRef] [PubMed]

188. Bharat, T.A.; Davey, N.E.; Ulbrich, P.; Riches, J.D.; de Marco, A.; Rumlova, M.; Sachse, C.; Ruml, T.; Briggs, J.A. Structure of the immature retroviral capsid at $8 \AA$ resolution by cryo-electron microscopy. Nature 2012, 487, 385-389. [CrossRef] [PubMed]

189. Schur, F.K.; Hagen, W.J.; Rumlova, M.; Ruml, T.; Muller, B.; Krausslich, H.G.; Briggs, J.A. Structure of the immature HIV-1 capsid in intact virus particles at $8.8 \AA$ resolution. Nature 2015, 517, 505-508. [CrossRef] [PubMed]

190. Zhou, Z.H. Atomic Resolution Cryo Electron Microscopy of Macromolecular Complexes. Adv. Protein Chem. Struct. 2011, 82, 1-35.

191. Lee, J.H.; de Val, N.; Lyumkis, D.; Ward, A.B. Model Building and Refinement of a Natively Glycosylated HIV-1 Env Protein by High-Resolution Cryoelectron Microscopy. Structure 2015, 23, 1943-1951. [CrossRef] [PubMed]

192. Wu, S.; Avila-Sakar, A.; Kim, J.; Booth, D.S.; Greenberg, C.H.; Rossi, A.; Liao, M.; Li, X.; Alian, A.; Griner, S.L.; et al. Fabs enable single particle cryoEM studies of small proteins. Structure 2012, 20, 582-592. [CrossRef] [PubMed]

193. Murin, C.D.; Fusco, M.L.; Bornholdt, Z.A.; Qiu, X.; Olinger, G.G.; Zeitlin, L.; Kobinger, G.P.; Ward, A.B.; Saphire, E.O. Structures of protective antibodies reveal sites of vulnerability on Ebola virus. Proc. Natl. Acad. Sci. USA 2014, 111, 17182-17187. [CrossRef] [PubMed] 
194. Hong, M.; Lee, P.S.; Hoffman, R.M.; Zhu, X.; Krause, J.C.; Laursen, N.S.; Yoon, S.I.; Song, L.; Tussey, L.; Crowe, J.E., Jr.; et al. Antibody recognition of the pandemic H1N1 Influenza virus hemagglutinin receptor binding site. J. Virol. 2013, 87, 12471-12480. [CrossRef] [PubMed]

195. Kong, L.; Giang, E.; Nieusma, T.; Kadam, R.U.; Cogburn, K.E.; Hua, Y.; Dai, X.; Stanfield, R.L.; Burton, D.R.; Ward, A.B.; Wilson, I.A.; Law, M. Hepatitis C virus E2 envelope glycoprotein core structure. Science 2013, 342, 1090-1094. [CrossRef] [PubMed]

196. Kong, L.; Lee, J.H.; Doores, K.J.; Murin, C.D.; Julien, J.P.; McBride, R.; Liu, Y.; Marozsan, A.; Cupo, A.; Klasse, P.J.; et al. Supersite of immune vulnerability on the glycosylated face of HIV-1 envelope glycoprotein gp120. Nat. Struct. Mol. Biol. 2013, 20, 796-803. [CrossRef] [PubMed]

197. Huang, J.; Kang, B.H.; Pancera, M.; Lee, J.H.; Tong, T.; Feng, Y.; Imamichi, H.; Georgiev, I.S.; Chuang, G.Y.; Druz, A.; et al. Broad and potent HIV-1 neutralization by a human antibody that binds the gp41-gp120 interface. Nature 2014, 515, 138-142. [CrossRef] [PubMed]

198. Murin, C.D.; Julien, J.P.; Sok, D.; Stanfield, R.L.; Khayat, R.; Cupo, A.; Moore, J.P.; Burton, D.R.; Wilson, I.A.; Ward, A.B. Structure of 2G12 Fab2 in complex with soluble and fully glycosylated HIV-1 Env by negative-stain single-particle electron microscopy. J. Virol. 2014, 88, 10177-10188. [CrossRef] [PubMed]

199. Yasmeen, A.; Ringe, R.; Derking, R.; Cupo, A.; Julien, J.P.; Burton, D.R.; Ward, A.B.; Wilson, I.A.; Sanders, R.W.; Moore, J.P.; Klasse, P.J. Differential binding of neutralizing and non-neutralizing antibodies to native-like soluble HIV-1 Env trimers, uncleaved Env proteins, and monomeric subunits. Retrovirology 2014, 11. [CrossRef] [PubMed]

200. Flyak, A.I.; Ilinykh, P.A.; Murin, C.D.; Garron, T.; Shen, X.; Fusco, M.L.; Hashiguchi, T.; Bornholdt, Z.A.; Slaughter, J.C.; Sapparapu, G.; et al. Mechanism of human antibody-mediated neutralization of Marburg virus. Cell 2015, 160, 893-903. [CrossRef] [PubMed]

201. Henderson, R. Avoiding the pitfalls of single particle cryo-electron microscopy: Einstein from noise. Proc. Natl. Acad. Sci. USA 2013, 110, 18037-18041. [CrossRef] [PubMed]

202. Mao, Y.; Castillo-Menendez, L.R.; Sodroski, J.G. Reply to Subramaniam, van Heel, and Henderson: Validity of the cryo-electron microscopy structures of the HIV-1 envelope glycoprotein complex. Proc. Natl. Acad. Sci. USA 2013, 110, E4178-E4182. [CrossRef] [PubMed]

203. Subramaniam, S. Structure of trimeric HIV-1 envelope glycoproteins. Proc. Natl. Acad. Sci. USA 2013, 110, E4172-E4174. [CrossRef] [PubMed]

204. Wasilewski, S.; Calder, L.J.; Grant, T.; Rosenthal, P.B. Distribution of surface glycoproteins on influenza A virus determined by electron cryotomography. Vaccine 2012, 30, 7368-7373. [CrossRef] [PubMed]

205. Zhang, X.; Sheng, J.; Austin, S.K.; Hoornweg, T.E.; Smit, J.M.; Kuhn, R.J.; Diamond, M.S.; Rossmann, M.G. Structure of acidic $\mathrm{pH}$ dengue virus showing the fusogenic glycoprotein trimers. J. Virol. 2015, 89, 743-750. [CrossRef] [PubMed]

206. Kostyuchenko, V.A.; Zhang, Q.; Tan, J.L.; Ng, T.S.; Lok, S.M. Immature and mature dengue serotype 1 virus structures provide insight into the maturation process. J. Virol. 2013, 87, 7700-7707. [CrossRef] [PubMed]

207. Zhang, X.; Ge, P.; Yu, X.; Brannan, J.M.; Bi, G.; Zhang, Q.; Schein, S.; Zhou, Z.H. Cryo-EM structure of the mature dengue virus at 3.5-Å resolution. Nat. Struct. Mol. Biol. 2013, 20, 105-110. [CrossRef] [PubMed]

208. Kostyuchenko, V.A.; Chew, P.L.; Ng, T.S.; Lok, S.M. Near-atomic resolution cryo-electron microscopic structure of dengue serotype 4 virus. J. Virol. 2014, 88, 477-482. [CrossRef] [PubMed]

209. Zhang, R.; Hryc, C.F.; Cong, Y.; Liu, X.; Jakana, J.; Gorchakov, R.; Baker, M.L.; Weaver, S.C.; Chiu, W. 4.4 $\AA$ cryo-EM structure of an enveloped alphavirus Venezuelan equine encephalitis virus. EMBO J. 2011, 30, 3854-3863. [CrossRef] [PubMed]

210. Ward, A.B.; Sali, A.; Wilson, I.A. Biochemistry. Integrative structural biology. Science 2013, 339, $913-915$. [CrossRef] [PubMed]

(C) 2016 by the authors; licensee MDPI, Basel, Switzerland. This article is an open access article distributed under the terms and conditions of the Creative Commons by Attribution (CC-BY) license (http:/ / creativecommons.org/licenses/by/4.0/). 